\title{
Dez medidas anticorrupção
}

\author{
Ministério Público Federal
}

\section{Medida 1}

Investimento em prevenção

\author{
1. Accountability
}

Anteprojeto de Lei

Prevê a criação de regras de accountability no âmbito dos Tribunais Regionais Federais, dos Tribunais de Justiça dos Estados e do Distrito Federal e Territórios e dos Ministérios Públicos respectivos, e dá outras providências.

\section{$[\ldots]$ \\ Justificativa}

A presente iniciativa legislativa possui a finalidade primordial de agilizar a tramitação das ações de improbidade administrativa e das ações criminais, com o estabelecimento de rotinas de accountability e eficiência em relação aos processos judiciais respectivos.

Busca-se, com isso, estimular a racionalidade do sistema judicial, permitindo que caminhe em direção ao cumprimento de seu escopo, bem como se almeja reforçar a responsabilidade proativa daqueles que melhor conhecem o 
sistema e seus percalços - os julgadores e membros do Ministério Público - , na busca das soluções mais adequadas. Cria-se, assim, um mecanismo automático de busca de soluções a partir do diagnóstico da situação.

O fato é que a morosidade na tramitação das ações de improbidade administrativa e das ações criminais é tão nefasta a ponto de o Conselho Nacional de Justiça (CNJ), órgão de controle externo do Poder Judiciário, estabelecer meta para as Justiças Estadual, Federal e Militar, e para o Superior Tribunal de Justiça, a fim de "identificar e julgar, até31/12/2013, as ações de improbidade administrativa e ações penais relacionadas a crimes contra a administração pública distribuídas até 31/12/2011" (Meta 18, de 2013).

No entanto, as metas estabelecidas pelo CNJ ficaram longe de alcançar o efeito desejado. Mesmo com os esforços concentrados realizados por juízes país afora, o Relatório de Metas Nacionais do Poder Judiciário 2009-2013 revelou que nenhum Tribunal do país logrou alcançar a meta.

De acordo com as informações prestadas pelos Tribunais, até 31 de dezembro de 2011 havia no Poder Judiciário um estoque de 43.773 ações de improbidade distribuídas e não julgadas. Mesmo com os esforços impostos pela Meta 18, de tais ações somente 10.643 foram julgadas no ano de 2012, e apenas outras 9.864 no ano de 2013.

Vê-se, portanto, que o problema da morosidade na tramitação dessas ações não será resolvido apenas com esforços concentrados e priorização de julgamentos. Para tanto, é necessário identificar os fatores que realmente influenciam na dificuldade de tramitação desses processos, e criar meios para destravá-los.

Nesse sentido, uma das possíveis soluções é a detecção dos problemas e das particularidades que envolvem julgamentos relativos à Lei no 8.429 , de 2 de junho de 1992, à Lei no 12.846 , de 1ํ de agosto de 2013, e aos crimes, por meio do estabelecimento de normas de accountability.

O que se pretende, portanto, é o estabelecimento de uma opção legislativa para, ao final, priorizar as ações que dizem respeito a atos de corrupção, por meio do efetivo conhecimento a respeito de como elas se desenvolvem.

É certo que as causas da morosidade na tramitação das ações de improbidade administrativa e das ações criminais, seguramente, não se resumem a esse aspecto procedimental. Não se ignora que uma série de fatores políticos e sociológicos também possui relevante papel na lentidão dessas ações, uma vez que comumente essas causas interferem em poderosos interesses econômicos e políticos e dizem respeito a réus que detêm influência social e meios financeiros para dificultar o andamento do processo judicial. 
No entanto, a existência de outros fatores não é justificativa para que não se resolvam os problemas decorrentes de incongruências procedimentais e estruturais; pelo contrário, deve-se implementar, ao máximo, os meios necessários para que o processo assegure a viabilização do interesse social na responsabilização dos autores de atos ímprobos, bem como o direito constitucional da sociedade de se valer de procedimento judicial célere para tanto.

\section{Teste de Integridade}

\section{Anteprojeto de Lei}

Cria o teste de integridade dos agentes públicos.

\section{$[\ldots]$}

Justificativa

Trata-se de iniciativa legislativa que almeja criar novo mecanismo voltado à defesa da moralidade pública.

Assim é que se pretende inovar o ordenamento jurídico para instituir o teste de integridade aos agentes públicos, de modo que sejam prevenidos atos de corrupção e comportamentos inadequados no serviço público e, particularmente, nos corpos policiais, tal como já realizado em grande extensão em outros países, a exemplo dos Estados Unidos da América, da Austrália, do Reino Unido, além da região administrativa especial de Hong Kong.

O objetivo central do teste de integridade é criar, preventivamente, a percepção de que todo o trabalho do agente público está sujeito a escrutínio e, a qualquer momento, a atividade pode estar sendo objeto de análise, inclusive sob o ponto de vista de honestidade. A realização do teste não parte da premissa da desconfiança sobre os servidores em geral, mas sim da noção de que todo agente público tem um dever de transparência e accountability, sendo natural o exame de sua atividade.

Prestigia-se, sob outra vertente, o Princípio Republicano, a partir do qual todos os agentes públicos devem prestar contas de sua atuação, e a Administração Pública deve velar pela correta e proba condução da coisa pública.

O teste de integridade dirigido é aplicado, então, no agente público em relação ao qual já houve algum tipo de notícia desairosa ou suspeita de prática ímproba, ao passo que os testes de integridade aleatórios refletem o princípio 
de que a atividade de qualquer agente público está sujeita, a qualquer tempo, a escrutínio.

O teste de integridade objetiva desencadear medidas proativas da Administração Pública para combater e prevenir a corrupção em situações enfrentadas corriqueiramente pelo agente público. Exemplo disso é o oferecimento de um valor módico, a título de propina, por um agente de corregedoria que, fingindo ser um cidadão comum, comete uma infração de trânsito e é parado por policial para ser multado. Há registro de resultados positivos em diversos locais nos quais esse tipo de teste foi e é utilizado, sendo recomendado até mesmo pela ONU e pela Transparência Internacional em relação às polícias. Além disso, esses dois organismos internacionais apontam que o conceito dos testes de integridade não precisa ser confinado às atividades policiais, daí que é possível aplicá-los em outros setores da Administração Pública.

Já na década de 70 do século $X X$, ao simular situações reais na cidade norte-americana de Miami, a $A B C$ News providenciou a entrega de 31 carteiras contendo dinheiro e identidade para 31 policiais, 9 dos quais subtraíram o dinheiro e foram penalizados.

Trinta anos depois, em Los Angeles e em Nova York, cidades nas quais as polícias aplicam, sistematicamente, testes de integridade nos policiais, a mesma rede de televisão distribuiu 20 carteiras para os policiais de cada cidade. Todas as carteiras foram devolvidas aos proprietários "sem nenhum centavo faltando", a demonstrar que a criação de um ambiente de transparência e escrutínio, no qual o agente público pode ser testado a qualquer momento, tende a modificar o comportamento e a cultura de corrupção. Destaque-se também, no exemplo, que, se a própria imprensa pode aplicar, de modo lícito, testes de integridade, tanto mais pode fazê-lo a Administração Pública.

No caso do teste de integridade, embora pudesse haver alguma discussão jurídica quanto à viabilidade de processamento criminal (e não cível ou administrativo) da situação, em razão da tese do flagrante preparado, há posições doutrinárias e jurisprudenciais favoráveis à legitimidade da persecução criminal de condutas apuradas por meio de tais testes, desde que sua aplicação seja cercada de alguns cuidados.

De todo modo, independentemente de tal discussão na seara criminal, há precedente do Supremo Tribunal Federal rejeitando a tese do flagrante preparado no tocante à aplicação de sanção administrativa. Para proteger o servidor público, ressalte-se, é vedada pelo projeto a realização de testes que representem uma tentação desmedida, a qual poderia levar uma pessoa honesta a se corromper. 
Com o mesmo objetivo, deverá ocorrer a comunicação prévia ao Ministério Público, informando-se a abrangência e os critérios de seleção usados, para aquela Instituição efetuar recomendações em 15 dias, se assim entender cabíveis. Além disso, para garantia do examinado, o teste deve ser sujeito à gravação audiovisual sempre que for possível.

\section{Percentuais de publicidade}

\section{Anteprojeto de Lei}

$[\ldots]$

\section{Justificativa}

Trata-se de iniciativa legislativa que almeja criar novos mecanismos voltados à defesa da moralidade pública e da probidade administrativa, quais sejam, a aplicação de percentuais mínimos de publicidade para ações e programas no âmbito da União, dos Estados, do Distrito Federal e Territórios e dos Municípios, bem como o estabelecimento de procedimentos e rotinas voltados à prevenção de atos de corrupção (art. 1º).

Assim é que o art. $2{ }^{\circ}$ introduz a obrigação de um gasto mínimo de publicidade para incentivar o desenvolvimento de uma cultura contra a corrupção, a qual, infelizmente, apresenta-se como um fenômeno endêmico, cuja mudança não depende apenas de acabar ou diminuir a sensação de impunidade, como também de ações de conscientização da população e de treinamento de agentes públicos para enfrentar situações de risco sem a flexibilização de regras éticas.

Um dos mais famosos exemplos bem-sucedidos de combate à corrupção é a experiência de Hong Kong. De uma situação de corrupção endêmica nos anos 1960, Hong Kong migrou para a 17a posição no ranking global de honestidade da Transparência Internacional, feito com base em índice de percepção de corrupção. A estratégia de Hong Kong alicerçou-se sobre três pilares.

Um deles é a investigação e punição dos culpados, afastando-se a sensação de impunidade. Os outros dois são a prevenção e a educação, que são o foco da presente medida. Em Hong Kong, houve forte campanha, feita em 
mídias de massa, para engajar a opinião pública na luta contra a corrupção pública e privada, não só incentivando a denúncia de atos corruptos, mas também conscientizando a população dos danos sociais e individuais decorrentes dessa prática.

A aceitação da corrupção na cultura social ocasiona sua assimilação em subculturas organizacionais. Evidência reveladora dessa conclusão é a pesquisa que mostra um índice de tolerância à corrupção política de 75\%, ou seja, 75\% dos brasileiros admitem que seriam capazes de cometer irregularidades em cargos públicos.

Diante desse número, não surpreende que parte relevante dos atos corruptos - como a corrupção de policiais no trânsito ou as fraudes em licitações - comece por atos de particulares. Um exemplo claro, grave e recente da corrupção privada foi exposto pelo noticiário "Fantástico" do dia 4 de janeiro de 2015, ao divulgar a existência de uma máfia de próteses, por meio da qual médicos receberiam uma "comissão" de 20\% a 30\% dos valores das próteses em troca da escolha de determinadas marcas.

Por outro lado, de nada adiantaria instituir, simplesmente, auditorias e sistemas de controle se não houver uma preocupação com a mudança da cultura de corrupção social e individual, pois o homem continuará buscando e encontrando brechas para manter o velho jogo oculto sob as novas regras.

Por isso é que também são propostas medidas mais amplas e com repercussão social. Assim, paralelamente à efetividade da punição do comportamento corrupto, deve-se realizar trabalho consistente de conscientização da população acerca dos malefícios coletivos e individuais que a corrupção acarreta, bem como para que reportem comportamentos corruptos. Há várias campanhas anticorrupção no mundo que utilizaram, intensivamente, propagandas veiculadas em meios de comunicação de massa a fim de contribuir com a mudança da cultura da corrupção pública e privada.

A análise do detalhamento dos dispêndios governamentais com publicidade revela uma tendência a ampliar os gastos com a publicidade institucional (que tem por objetivo divulgar atos, obras e programas do governo), em detrimento da publicidade de utilidade pública (que visa informar e orientar a população para adotar comportamentos que lhe tragam benefícios reais).

Com efeito, comparando-se as Leis Orçamentárias Anuais de 2013 e 2014, verifica-se que a previsão de gastos com a primeira modalidade cresceu 33,8\%, passando de R\$ 202,8 milhões em 2013 para R\$ 270,1 milhões em 2014. Já a publicidade voltada à utilidade pública teve seu orçamento reduzido de R\$ 728,7 milhões em 2013 para R\$ 592,2 milhões em 2014. De qualquer sorte, 
o gasto do Governo Federal com publicidade, apenas para a Administração Pública Direta (excluindo-se as empresas públicas), alcançaria R\$ 863,4 milhões em 2014.

Assim, é factível especificar que uma parcela desses recursos seja direcionada a campanhas de prevenção à corrupção, como faz a proposta alinhavada no art. $2 \stackrel{0}{\circ}$

A proposta de alocação de um percentual dos recursos gastos em propaganda tem, ainda, o condão de melhor especificar o destino do orçamento de publicidade, o qual, muitas vezes, já é, por si só, fonte de corrupção - consoante visto a partir do julgamento da Ação Penal 470 ("Mensalão") em relação ao desvio de recursos promovido por meio de verbas publicitárias pagas à empresa SMP\&B, do condenado Marcos Valério de Souza.

Evitando-se possíveis questionamentos acerca da legitimidade e da licitude do uso de imagens e de sons de casos concretos de corrupção, o §5ํ introduzido no art. $2^{\circ}$ expressamente dispõe que é desnecessária a identificação de criminosos na propaganda institucional contra a corrupção, de modo que aconteça uma ponderação com o princípio constitucional da intimidade.

A inspiração da norma do aludido §5ㅇe é que o impacto das ações de marketing é maior quando se correlaciona a mensagem a casos concretos de conhecimento público. De fato, o impacto da publicidade será maior se o cidadão entender que atos de corrupção do dia a dia podem ser tão nefastos quanto aqueles vistos nos grandes escândalos de corrupção.

Já o $\S^{\circ}$ o proposto no art. 2o busca dar solução para uma das maiores dificuldades no combate à corrupção policial, que é a relutância do cidadão em noticiar a corrupção da polícia à própria polícia, dando publicidade ao órgão externo para o qual o cidadão pode comunicá-la. A realização da comunicação ao Ministério Público justifica-se porque foi ele consagrado na Constituição Federal como a Instituição responsável pelo controle externo da atividade policial.

Ao mesmo tempo, o destaque no texto para esse assunto, assim como a obrigatoriedade de placas contendo a informação em rodovias justificam-se porque a corrupção de trânsito em rodovias é uma das mais notórias tipologias de corrupção brasileiras, daí que, enquanto não for eficazmente combatida, será difícil mudar o índice de percepção da corrupção no Brasil.

$\mathrm{O}$ art. 3o, por sua vez, exige a realização de treinamentos e o estabelecimento de regras específicas contra a corrupção, realizados por órgãos internos e externos de prevenção e combate à corrupção, o que tem por escopo modificar subculturas organizacionais voltadas a essa prática ilícita. 
Nesse sentido, o dispositivo prevê a realização de cursos periódicos a agentes públicos, para que se conscientizem sobre as atitudes a tomar diante da oferta direta de vantagens por particulares ou em face de situações que potencialmente possam caracterizar atos de corrupção. Os cursos objetivam, também, neutralizar as racionalizações, isto é, os processos psicológicos nos quais o agente busca justificativas para a aceitação de comportamentos ilegais. Paralelamente, o artigo prevê a edição e a publicidade de códigos de conduta para regular o comportamento dos agentes públicos.

O estabelecimento de regras claras sobre corrupção e o treinamento dos agentes públicos constituem a base para qualquer programa efetivo de compliance, o que vem sendo objeto de atenção mundial. Nessa linha, em países onde o estudo das regras de integridade é mais avançado, a comunicação e o treinamento adequados figuram, inclusive, como balizadores do efetivo comprometimento das organizações com a prevenção à corrupção.

Na mesma direção, o §7ำ do art. 3o estimula o ensino e o debate da ética em escolas e universidades, contribuindo com a formação de uma cultura contra a corrupção.

Por fim, o $\S 8^{\circ}$ do mesmo artigo atende a uma recomendação internacional no combate à corrupção, qual seja, dar visibilidade à existência de valores a serem pagos por serviços em repartições públicas. A disseminação da informação sobre a gratuidade ou a necessidade de pagar algum valor cria um ambiente de transparência e evita que o cidadão entenda que está sendo cobrado indevidamente quando o valor é devido, ou que o agente público possa cobrar o cidadão por um serviço gratuito.

\section{Sigilo da fonte}

\section{Anteprojeto de Lei}

Disciplina, nos termos do art. 5ㅇ, inciso XIV, da Constituição Federal, o sigilo da fonte da informação que deu causa à investigação relacionada à prática de atos de corrupção.

\section{Justificativa}

Trata-se de iniciativa legislativa que almeja criar novo mecanismo voltado à defesa da moralidade pública e da probidade administrativa, qual seja, 
regular o sigilo da fonte da informação que deu causa à investigação relacionada à prática de atos de corrupção.

De fato, pretende-se introduzir a figura do informante confidencial, distinguindo-o do informante anônimo, cuja identidade se desconhece.

É que a identidade do informante confidencial será conhecida, mas não revelada por importante razão de interesse público. O objetivo central da regra é criar um ambiente no qual os cidadãos que têm conhecimento de atos corruptos noticiem a prática ilícita, mesmo quando temem algum risco à sua integridade física ou à de alguém próximo, o que é bastante comum.

Cuida-se de significativo avanço para que se ultrapasse a primeira barreira que impede a descoberta (e consequente punição) de atos corruptos: a dificuldade dos órgãos de persecução de receberem notícias sobre a existência dos fatos corruptos.

Na experiência da região administrativa especial de Hong Kong, a propósito, o slogan central da primeira fase do processo de mudança de cultura, desde os anos relativos à década de 1970, foi "reporte a corrupção".

Diz-se expressamente, embora seja evidente, que ninguém poderá ser condenado com base exclusivamente no depoimento de um informante confidencial, já que não terá sido possível à defesa avaliar criticamente a credibilidade do depoente. O comum, contudo, é que se obtenham provas materiais do ato corrupto após uma notícia de corrupção. A preservação da identidade do informante só existe na medida em que ele não incrimine falsamente alguém.

Além disso, caso o juiz entenda imprescindível a revelação da identidade do informante, o Ministério Público poderá escolher entre revelar a identidade e perder o valor probatório exclusivamente do depoimento prestado pelo informante. Tal opção tem por base o art. 5ำ, inciso XIV, da Constituição Federal.

Com frequência, testemunhas comparecem voluntariamente ao Ministério Público e condicionam seu depoimento sobre certo fato, até então desconhecido das autoridades públicas, à preservação da confidencialidade de sua identidade, diante dos riscos à sua integridade física. A preservação da fonte nesses casos é essencial ao trabalho do Ministério Público, na defesa dos direitos fundamentais sociais e daqueles direitos fundamentais tutelados pelas normas penais.

Esse tipo de conduta não é novidade, sendo há muito tempo reconhecido no direito norte-americano e é extraível, mediante interpretação, do art. 5o, inciso XIV, da Constituição Federal. A previsão expressa, contudo, objetiva conferir segurança jurídica à testemunha que colabora sobre fato inédito, 
sob condição de confidencialidade, cujo depoimento não poderia ser obtido sem garantia de sigilo.

Dita norma incentivará as pessoas não só a informar crimes já cometidos, contribuindo com a investigação, mas também crimes em vias de serem cometidos, constituindo importante medida para prevenir a prática ou a continuidade de esquemas criminosos.

\section{Medida 2}

\section{Criminalização do enriquecimento ilícito de agentes públicos e proteção à fonte de informação}

\section{Enriquecimento ilícito}

\section{Anteprojeto de Lei}

Acrescenta o art. 312-A ao Decreto-Lei no 2.848, de 7 de dezembro de 1940 - Código Penal, para tornar crime o enriquecimento ilícito de agentes públicos.

$[\ldots]$

Justificativa

A redação do tipo penal acima, com exceção da pena (originalmente de um a cinco anos e hoje de dois a cinco anos) e da conduta de possuir, é a que consta no parecer da Comissão Temporária de Estudo da Reforma do Código Penal (Relator Senador Pedro Taques). A pena de 3 a 8 anos é a mesma pena desse crime que foi proposta pelo Projeto de Lei 5.586/2005, oferecido pela Controladoria-Geral da União.

O enriquecimento ilícito de servidor público decorre comumente da prática de corrupção e crimes conexos. No entanto, como ressaltado no projeto, é muito difícil punir o crime de corrupção, salvo quando uma das partes revela sua existência, o que normalmente não acontece. Por essa razão, a Convenção das Nações Unidas contra a Corrupção, da qual o Brasil é signatário, exorta os Estados Partes a tipificarem em seus ordenamentos jurídicos o crime de enriquecimento ilícito, definido como o incremento significativo do patrimônio de um funcionário público por ingressos que não podem ser razoavelmente justificados por ele.

Por outro lado, o enriquecimento ilícito, além de ser prova indireta da corrupção, é em si mesmo desvalorado, pois revela um agir imoral e ilegal de 
servidor público, de quem se espera um comprometimento mais significativo com a lei do que se espera do cidadão comum. Há aqui um desvalor no tocante à discrepância patrimonial, não raro oculta ou disfarçada, de um agente público sujeito a regras de escrutínio, transparência e lisura.

Sobre esse tipo penal, o Relator da Comissão Temporária de Estudo da Reforma do Código Penal assim se manifestou:

Não restam dúvidas sobre a necessidade e as vantagens práticas de criminalização dessa gravíssima conduta, intimamente relacionada com delitos cometidos contra a Administração Pública. A fundamentação está muito bem colocada na Exposição de Motivos do Projeto de Código:

"Enriquecimento ilícito. Objeto de tratados internacionais firmados pelo Brasil, a criminalização do enriquecimento ilícito mostra-se como instrumento adequado para a proteção da lisura da administração pública e o patrimônio social. Não cabe ignorar que o amealhamento de patrimônio incompatível com as rendas lícitas obtidas por servidor público é indício de que houve a prática de antecedente crime contra a administração pública. Notadamente a corrupção e o peculato mostram-se caminhos prováveis para este enriquecimento sem causa. A riqueza sem causa aparente mostra-se, portanto, indício que permitirá a instauração de procedimentos formais de investigação, destinados a verificar se não houve aquisição patrimonial lícita. Não há inversão do ônus da prova, incumbindo à acusação a demonstração processual da incompatibilidade dos bens com os vencimentos, haveres, recebimentos ou negociações lícitas do servidor público. Não se pode olvidar que o servidor público transita num ambiente no qual a transparência deve reinar, distinto do que ocorre no mundo dos privados, que não percebem recursos da sociedade. Daí obrigações como a entrega da declaração de bens a exame pelo controle interno institucional e pelo Tribunal de Contas. O crime de enriquecimento ilícito, especificamente diante da corrupção administrativa, na qual corruptor e corrupto guardam interesse recíproco no sigilo dos fatos, sinaliza política criminal hábil, buscando consequências e não primórdios (a exemplo da receptação e da lavagem de dinheiro). É criminalização secundária, perfeitamente admitida em nosso direito. Vocaciona-se para dificultar a imensa e nefasta tradição de corrupção administrativa que, de acordo com índices de percepção social, nunca se deteve". 
[...] Oportuno registrar que, como regra, a conduta de enriquecimento ilícito não gerará a adoção do encarceramento, pois (se preenchidos os requisitos legais) será permitida a substituição da pena privativa de liberdade por restritivas de direitos. Ou seja, apenas as situações mais graves ensejariam a imposição de penas de prisão.

As penas propostas para os graves delitos de prevaricação e advocacia administrativa não alteram o quadro vigorante na década de 40 do século passado, quando da edição do CP. Diante da necessidade de haver uma proporcional e devida repressão a esses crimes, que ocorrem com grande frequência, e que normalmente prescrevem em razão das baixíssimas penas, propomos os devidos aumentos.

Mesmo com o aumento de pena proposto aqui, continuarão as penas a serem substituídas nos casos de delitos menos graves.

Reforça-se que não se trata de uma inversão do ônus da prova no tocante ao caráter ilícito da renda, mas sim de acolher a única explicação para a discrepância que é encontrada em dado caso concreto, após investigados os fatos e ouvido o servidor. Essa solução é amparada na moderna teoria explanacionista da prova, que tem por foco encontrar a hipótese que melhor explica a evidência disponível, bem como na tradicional teoria indutiva, que foca em associações entre coisas que estão normalmente vinculadas com base na experiência que todos compartilhamos e é o fundamento de qualquer exame sobre provas.

Em outras palavras, com base na experiência comum por todos compartilhada, se a acusação prova a existência de renda discrepante da fortuna acumulada e, além disso, nem uma investigação cuidadosa nem o investigado apontam a existência provável de fontes lícitas, pode-se concluir que se trata de renda ilícita. Evidentemente, se a investigação ou o acusado forem capazes de suscitar dúvida razoável quanto à ilicitude da renda, será caso de absolvição.

\section{Medida 3}

\section{Corrupção com pena maior e como crime hediondo segundo o valor}

\section{Corrupção como crime hediondo}




\section{Anteprojeto de Lei}

$[\ldots]$

\section{Justificativa}

1. Alteração das penas dos crimes mais lesivos contra a Administração Pública previstos no Código Penal

As mudanças propostas objetivam fazer da corrupção, termo usado aqui em sentido amplo, uma conduta de alto risco.

A corrupção é hoje um crime de baixo risco, com pena iniciando em dois anos de prisão. Criminosos de colarinho-branco normalmente são primários, e as penas ficam próximas do mínimo legal. Quando há condenação e não prescrevem, as penas são substituídas, por força de lei, por penas restritivas de direitos, isto é, por penas bem brandas, as quais, em pouco tempo (em regra após cumprido apenas um quarto da pena substitutiva), serão atingidas por indultos ou comutações, reduzindo-se a nada ou quase nada. Considerando que a corrupção é um crime difícil de ser descoberto e provado, o criminoso só será punido em uma pequena parcela dos crimes que cometer, o que faz dela um crime altamente vantajoso.

A elevação da pena mínima dos crimes mais graves contra a Administração Pública para quatro anos significa que mesmo réus primários - e os réus de colarinho-branco normalmente são primários mesmo quando praticaram crimes antes - não terão suas penas substituídas por penas restritivas de direitos e começarão a cumprir a pena, na melhor das hipóteses, em regime semiaberto. Ninguém que praticar corrupção poderá contar com um regime aberto, o qual, em muitos casos, na prática, por falta de casa de albergado e de fiscalização, significa pena nenhuma. 
Adicione-se que a pena mínima atual, de dois anos, bastante aplicada nos casos desses crimes em razão do método de fixação da pena do nosso sistema, acarreta a prescrição em apenas quatro anos, o que tende a acontecer como regra em processos de crimes do colarinho-branco. Uma pena maior permite também um prazo mais dilatado para a sua investigação e processamento sem que o crime prescreva, o que é necessário, em decorrência de ser normalmente um crime de apuração complexa, praticado às escondidas.

Como o furto e o roubo, a corrupção suprime patrimônio. Diferentemente do furto e roubo, a corrupção endêmica brasileira vitimiza a nação. A corrupção rouba a comida, o remédio e a escola de milhões de pessoas, prejudicando o futuro de todos. Essas circunstâncias acentuam bastante sua gravidade e também justificam a pena mínima proposta como uma reprovação proporcional ao gravame. Cumpre observar, aliás, que há projetos de lei em trâmite que sugerem penas ainda maiores para alguns dos crimes (PL 7.868/2014, por exemplo, estabelece a pena inicial de cinco anos para o peculato e a concussão), enquanto outras estabelecem o patamar idêntico ao proposto (PL 5.900/2013).

Se queremos um país livre de corrupção, esta deve ser transformada em um crime de alto risco. Como o homicídio, a corrupção mata. Contudo, diferentemente da maior parte dos homicídios, a corrupção é planejada e pensada, ou seja, é uma decisão racional que toma em conta custos e benefícios. A elevação da pena mínima constitui um desincentivo, um custo, da escolha pelo ato corrupto.

Quanto à gradação das penas desses crimes, embora entre as circunstâncias judiciais do art. 59 do Código Penal, que regulam a individualização da pena, já se encontrem as consequências do crime, o valor do prejuízo ou da vantagem econômica constitui, no contexto normativo atual, apenas mais um dos fatores considerados na dosimetria da pena, que sempre parte do mínimo legal.

Contudo, em crimes contra a Administração Pública, o volume da supressão de recursos do Estado, além de ser a principal circunstância a ser sopesada, pode engendrar consequências gravíssimas. Os milhões, ou bilhões, suprimidos dos cofres públicos inevitavelmente afetam as diversas camadas da população em seus direitos essenciais, como segurança, saúde, educação (isto é, furtam-lhes a possibilidade de um futuro melhor) e, em última análise, a própria vida. Embora seja difícil, em concreto, estabelecer-se o nexo causal entre os desvios de verbas e a morte de pessoas (tendo em vista que a ofensa é difusa), não há dúvidas de que o desvio de verbas públicas em escala acentuada acaba por provocar mortes. 
O parâmetro de pena razoável nesses casos deve ser o crime de homicídio, cuja pena, quando simples, é de seis a vinte anos, e, quando qualificado, é de doze a trinta anos. Outro parâmetro razoável, para corrupção de grande magnitude, é o crime de latrocínio, que tem pena de vinte a trinta anos, e o delito de extorsão qualificada pela morte, cuja pena é de vinte a trinta anos.

Por coerência, propôs-se igualmente a gradação da pena quando se tratar de crime de estelionato contra o erário ou contra a previdência social, os quais entram também na categoria dos mais graves crimes praticados contra a população e merecem ser apenados de acordo com o montante do prejuízo.

$\mathrm{O}$ aumento da pena proporcionalmente ao dano causado ou à vantagem ilícita auferida é adotado em outros países, inclusive com democracias mais avançadas e instituições mais amadurecidas e consolidadas, como, por exemplo, os Estados Unidos da América.

Com efeito, o 2014 USSC Guidelines Manual (Manual de Orientações da Comissão de Penas dos Estados Unidos, vigente a partir de novembro de 2014), que orienta os juízes e tribunais estadunidenses na dosimetria das penas criminais naquele país, determina que, se a vantagem auferida ou o dano ao Erário supera 5 mil dólares, a pena base passa a sofrer acréscimo proporcional, de acordo com a seguinte tabela:

\begin{tabular}{l|l}
\hline \multicolumn{1}{c|}{ Loss (Apply the Greatest) } & \multicolumn{1}{c}{ Increase in Level } \\
\hline (A) $\$ 5,000$ or less & no increase \\
\hline (B) More than $\$ 5,000$ & add 2 \\
\hline (C) More than $\$ 10,000$ & add 4 \\
\hline (D) More than $\$ 30,000$ & add 6 \\
\hline (E) More than $\$ 70,000$ & add 8 \\
\hline (F) More than $\$ 120,000$ & add 10 \\
\hline (G) More than $\$ 200,000$ & add 12 \\
\hline (H) More than $\$ 400,000$ & add 14 \\
\hline (I) More than $\$ 1,000,000$ & add 16 \\
\hline (J) More than $\$ 2,500,000$ & add 18 \\
\hline (K) More than $\$ 7,000,000$ & add 20 \\
\hline (L) More than $\$ 20,000,000$ & add 22 \\
\hline (M) More than $\$ 50,000,000$ & add 24 \\
\hline (N) More than $\$ 100,000,000$ & add 26 \\
\hline (O) More than $\$ 200,000,000$ & add 28 \\
\hline (P) More than $\$ 400,000,000$ & add 30 \\
\hline
\end{tabular}


Essa tabela impõe um acréscimo à pena-base, que pode variar entre 6 meses (acima de 5 mil dólares de vantagem auferida) até o máximo de 10 anos (acima de 400 milhões de dólares de vantagem auferida) de aprisionamento, para o réu primário.

Com base na proposta, apresenta-se abaixo o quadro de penas, em anos, por ato criminoso, que passariam a vigorar para os principais crimes contra a Administração Pública, com base no salário mínimo vigente a partir de 1을 janeiro de 2015, ressaltando que a primeira coluna retrata as penas que hoje são cominadas pelo Código Penal:

\begin{tabular}{|c|c|c|c|c|c|}
\hline \multirow{2}{*}{ Crime } & \multirow{2}{*}{$\begin{array}{l}\text { Pena } \\
\text { atual }\end{array}$} & \multicolumn{4}{|c|}{ Proposta: pena variável pelo prejuízo ou benefício (R\$) } \\
\hline & & 0 a $77.999,99$ & $\geq 78.800,00$ & $\geq 788.000,00$ & $\geq 7.880 .000,00$ \\
\hline $\begin{array}{l}\text { Peculato } \\
\text { (art. } 312 \text { e } \S 1^{\circ} \text { ) }\end{array}$ & 2 a 12 & 4 a 12 & 7 a 15 & 10 a 18 & 12 a 25 \\
\hline $\begin{array}{l}\text { Inserção de } \\
\text { dados falsos } \\
\text { em sistema de } \\
\text { informações } \\
\text { (art. 313-A) }\end{array}$ & 2 a 12 & 4 a 12 & 7 a 15 & 10 a 18 & 12 a 25 \\
\hline $\begin{array}{l}\text { Concussão } \\
\text { (art. 316) }\end{array}$ & 2 a 8 & 4 a 12 & 7 a 15 & 10 a 18 & 12 a 25 \\
\hline $\begin{array}{l}\text { Excesso } \\
\text { de exação } \\
\text { qualificada } \\
\text { (art. } 316, \S 2^{\circ} \text { ) }\end{array}$ & 2 a 12 & 4 a 12 & 7 a 15 & 10 a 18 & 12 a 25 \\
\hline $\begin{array}{l}\text { Corrupção } \\
\text { passiva } \\
\text { (art. 317) }\end{array}$ & 2 a 12 & 4 a 12 & 7 a 15 & 10 a 18 & 12 a 25 \\
\hline $\begin{array}{l}\text { Corrupção } \\
\text { ativa (art. 333) }\end{array}$ & 2 a 12 & 4 a 12 & 7 a 15 & 10 a 18 & 12 a 25 \\
\hline $\begin{array}{l}\text { Estelionato } \\
\text { (art. 171) }\end{array}$ & 1 a 5 & 2 a 8 & 4 a 10 & 6 a 12 & 8 a 14 \\
\hline
\end{tabular}

Parece ser instintivo que as condutas que representam dano maior devem ser mais severamente apenadas, não só como retribuição, mas, sobretudo, pelo seu caráter dissuasório. Por essa razão é que se propõe que a proporcionalidade entre o resultado lesivo e a sanção criminal seja expressamente prevista em 
relação aos mais graves crimes do colarinho-branco praticado com abuso de função pública ou em prejuízo ao Erário, cujo potencial de danos é tão grande quanto o de crimes de violência. Corrupção mata e deve ser uma conduta de alto risco, risco esse que deve ser proporcional ao gravame que pesará sobre a população.

Por fim, tendo em vista a necessidade de adaptar os princípios da moderna Justiça Restaurativa também aos crimes praticados contra os interesses difusos, é que se propõe que a obtenção de benefícios e favores legais relacionados ao cumprimento da pena seja condicionada à reparação do dano e à devolução da riqueza indevidamente amealhada.

2. Supressão da regulação específica do crime de corrupção praticado no contexto tributário, previsto no art. 3o da Lei 8.137, de 1990, e do crime de peculato praticado por prefeito, do art. 1o, I, do Decreto-Lei no 201, de 1967

A proposta não suprime o crime de corrupção praticado no contexto tributário ou o crime de peculato praticado por prefeito, mas apenas suprime sua regulação especial pela Lei 8.137/1990 e pelo Decreto-Lei 201/1967. Com a alteração proposta, a corrupção praticada no contexto tributário e o peculato de prefeito passam a ser previstos e punidos diretamente pelo Código Penal. Isso evita regulações adicionais e desnecessárias, bem como a necessidade de reproduzir na lei especial a gradação da pena da corrupção segundo o proveito econômico, que foi proposta no âmbito do Código Penal. A previsão especial, aliás, tende a gerar distorções a longo prazo. Projetos em trâmite no Congresso, que tornam hediondos a corrupção e o peculato, por exemplo, sequer mencionam esses tipos penais, o que tornaria hedionda a corrupção e o peculato de forma geral e não a corrupção no contexto tributário e o peculato praticado por prefeito. Isso, por si só, já seria ilógico, mas se torna mais aberrante se percebermos que tradicionalmente esses crimes especiais têm uma pena maior do que o crime de corrupção em geral. Uma vez que não há razão para privilegiar auditores-fiscais ou prefeitos que cometem crime de corrupção, é proposta a supressão nesses artigos.

3. Inclusão da corrupção no rol de crimes hediondos do art. 1o da Lei nº 8.072, de 1990

Esta proposta também está no contexto de fazer da corrupção um crime de alto risco patrimonial e moral, especialmente a corrupção de altos valores, 
porque esta produz consequências mais sérias. Se queremos um país livre de corrupção, ela deve ser transformada em um crime de alto risco, e esse risco deve corresponder à gravidade da conduta.

A corrupção rouba a comida, o remédio e a escola de milhões de pessoas, prejudicando o futuro de todos. Como se disse acima, a corrupção afeta a população em "seus direitos essenciais, como segurança, saúde e, em última análise, vida". "Embora seja difícil, em concreto, estabelecer-se o nexo causal entre os desvios de verbas e a morte de pessoas, não há dúvidas de que o desvio de verbas públicas em escala acentuada acaba por provocar mortes. O parâmetro de pena razoável nesses casos deve ser o crime de homicídio, cuja pena, quando simples, é de seis a vinte anos, e, quando qualificado, é de doze a trinta anos."

O Projeto de Lei no 3.506/2012 - um dos vários no Congresso que buscam estabelecer a corrupção como crime hediondo - , em sua justificativa, menciona uma reportagem da revista Veja, de 26 de outubro de 2011, que busca fazer um vínculo concreto entre a corrupção e os danos à sociedade. A matéria ressalta que os $\mathrm{R} \$ 85$ bilhões desviados mediante corrupção no ano de 2010 poderiam ser empregados para: "1 - Erradicar a miséria; 2 - Custear 17 milhões de sessões de quimioterapia; 3 - Custear 34 milhões de diárias de UTI nos melhores hospitais; 4 - Construir $241 \mathrm{~km}$ de metrô; 5 - Construir $36.000 \mathrm{~km}$ de rodovias; 6 - Construir 1,5 milhão de casas; 7 - Reduzir 1,2\% na taxa de juros; 8 - Dar a cada brasileiro um prêmio de R\$443,00 reais; 9 - Custear 2 milhões de bolsas de mestrado; e 10 - Comprar 18 milhões de bolsas de luxo".

Em nota técnica de apoio ao Projeto de Lei no 5.900/2013, a Associação Nacional dos Procuradores da República consigna que, com base em dados do Programa das Nações Unidas para o Desenvolvimento, são desviados do Brasil ao menos R\$ 200 bilhões por ano. Isso é quase duas vezes o total do orçamento federal da saúde de 2014, o que significa que a qualidade da saúde no Brasil (no que depende de verbas federais) poderia ser triplicada caso se fechassem as torneiras da corrupção. $O$ valor é aproximadamente duas vezes e meia maior do que o orçamento federal da educação, o que poderia também, pelo menos, triplicar a qualidade da educação, no que depende de verbas federais. Já quanto ao investimento federal em ciência, tecnologia e inovação, poderia ser multiplicado por 30 vezes. Poderia ser duplicado o programa "Minha Casa, Minha Vida", que entregou aproximadamente 1,7 milhão de casas populares.

Passou da hora de se reconhecer a gravidade concreta desse crime, especialmente quando os valores envolvidos são elevados. A inclusão da corrupção em sentido amplo entre os crimes hediondos é um reconhecimento de que 
são crimes que atentam, direta e indiretamente, contra direitos fundamentais da população.

Como são crimes que possuem motivação e consequências econômicas, é natural a inserção de um parâmetro econômico para a configuração de sua hediondez. Pela proposta, crimes como corrupção e peculato passam a ser hediondos quando o valor envolvido supera cem salários mínimos, o que em valores atuais representa $\mathrm{R}$ \$ 78.800,00. Quanto maiores os valores econômicos, maior o dano social, até um ponto em que o prejuízo social pode ser equiparado ao de outros crimes extremamente graves, que são delitos hediondos. Crimes como corrupção e peculato, quando envolvem cem vezes o valor que é, não raro, tudo que pessoas têm para passar o mês - um salário mínimo podem ser, sem dúvidas, caracterizados como hediondos, ainda mais dentro de um contexto de compromisso do Estado em combater a corrupção.

Some-se que, na linha do que figura nesta proposta, a pena desses crimes contra a Administração Pública, com proporção econômica superior a cem salários mínimos, varia no mínimo entre 7 e 15 anos. Esse patamar de pena é harmônico com outros crimes considerados hediondos pela lei, como estupro, cuja pena varia de 6 a 10 anos em sua forma simples, ou ainda o favorecimento da prostituição ou outra forma de exploração sexual de criança ou adolescente ou de vulnerável, com pena de 4 a 10 anos.

Reflexo do reconhecimento social da hediondez é o fato de que há numerosos projetos de lei propostos no Congresso, desde 1992, que objetivam transformar corrupção em crime hediondo, até mesmo independentemente do valor envolvido.

Como já dito anteriormente, a corrupção é hoje um crime de baixo risco. Quando há condenação e as penas não prescrevem, elas são brandas (não prisionais) e, em pouco tempo, serão atingidas por indultos ou comutações, reduzindo-se a nada ou quase nada. A atribuição da qualidade de crime hediondo às modalidades mais graves de corrupção terá como um dos efeitos positivos impedir a concessão de indulto e comutação de pena aos criminosos. Tal restrição só pode acontecer por iniciativa do Congresso Nacional, aliás, pela inserção de tais crimes na categoria de crimes hediondos, para os quais a própria Constituição veda os benefícios de indulto e comutação, já que de outro modo a concessão destes está dentro da esfera de prerrogativas do Presidente da República.

Além disso, segundo estudos consagrados sobre corrupção, como os de Rose-Ackerman e Klitgaard, uma das perspectivas do ato corrupto apresenta-o como fruto de uma decisão racional que toma em conta os benefícios e 
os custos da corrupção e os do comportamento honesto. A ponderação dos custos da corrupção envolve o montante da punição e a probabilidade de tal punição ocorrer. A inserção de tais delitos como hediondos repercute diretamente no montante da punição, sob prisma prático, pesando como fator negativo na escolha racional do agente.

É extremamente raro que autores de crimes de colarinho-branco sejam punidos e, quando punidos, que cumpram pena em regime fechado, mesmo quando os crimes são extremamente graves. A perspectiva de pena mais grave, e de condições mais gravosas de cumprimento de pena, será certamente um fator de desestímulo a tais práticas criminosas. No cenário atual, em que grandes esquemas de corrupção são descobertos, é preciso adotar medidas firmes para mudar a realidade.

\section{Medida 4}

\section{Aperfeiçoamento do sistema recursal penal}

\section{Recurso manifestamente protelatório}

\section{Anteprojeto de Lei}

Acresce ao Decreto-Lei no 3.689, de 3 de outubro de 1941 - Código de Processo Penal - o art. 580-A, para disciplinar o trânsito em julgado de recursos manifestamente protelatórios.

\section{$[\ldots]$}

\section{Justificativa}

A questão relativa ao trânsito em julgado é das mais sensíveis no âmbito da legislação processual, penal ou civil.

De um lado, há o direito constitucional da parte sucumbente de recorrer para que seja definitivamente afastada qualquer injustiça e, de outro, a necessidade de o processo ter uma duração razoável, de modo que a sensação de impunidade não se propague no seio da sociedade.

É por isso que é premente a necessidade de a decisão judicial revestir-se com a qualidade da coisa julgada. 
Por outro lado, o sistema recursal brasileiro, seja no âmbito penal, seja no âmbito civil, dificulta sobremaneira o advento do trânsito em julgado e, mais ainda, propicia o uso dos mais variados recursos tendentes a afastar o trânsito em julgado.

Nesse contexto é que são, em larga medida, utilizadas manobras recursais que, longe de configurarem o legítimo exercício do direito de recorrer, são, isto sim, a representação de seu abuso e do descaso com a Justiça. De fato, simples consulta aos sítios eletrônicos de Tribunais de todo o Brasil e, particularmente, das Cortes Superiores, aponta para o uso indiscriminado de recursos com a intenção única de dilargar o termo final do processo.

Por essa razão, a presente iniciativa legislativa pretende estabelecer que, uma vez que o Órgão Julgador (o qual deve ser, necessariamente, um Tribunal) tenha como manifestamente protelatório o recurso ou considere abusivo o direito de recorrer, deverá certificar o trânsito em julgado da decisão contra a qual se recorre e ordenar o imediato regresso dos autos à origem.

Além disso, o eventual recurso ou sucedâneo recursal que seja protocolado contra a decisão do Tribunal não possuirá efeito suspensivo, vale dizer, os efeitos da decisão deverão ser automaticamente levados em consideração.

Outro importante aspecto é que tal decisão acontecerá tanto para o Processo Penal quanto para o Processo Civil.

Cuida-se de iniciativa legislativa que pretende, assim, tornar mais célere o julgamento de processos, sem olvidar a necessidade da existência do duplo grau de jurisdição.

\section{Pedido de vistas nos Tribunais}

\section{Anteprojeto de Lei}

Acresce ao Decreto-Lei no 3.689, de 3 de outubro de 1941 - Código de Processo Penal - o art. 578-A, para disciplinar os pedidos de vistas no âmbito dos tribunais.<smiles>[AlH2]</smiles>

\section{Justificativa}

A questão relativa à morosidade dos julgamentos nos Tribunais e nas Cortes Superiores é das mais sensíveis no âmbito da legislação processual, penal ou civil. 
De um lado, há o natural desejo de as questões colocadas em julgamento serem apreciadas da forma mais cuidadosa e abrangente possível e, de outro, a necessidade de o processo ter uma duração razoável, de modo que a sensação de impunidade não se propague no seio da sociedade.

Nesse contexto, é imperiosa a regulação dos pedidos de vistas por membros de tribunais, de modo tal que haja previsibilidade quanto ao julgamento dos recursos ou sucedâneos recursais apresentados. De fato, simples consulta aos sítios eletrônicos de Tribunais de todo o Brasil mostra que alguns processos perduram em demasia (algumas vezes, longos anos) caso haja pedido de vistas, tudo a implicar atraso inaceitável para o processo.

Por essa razão, a presente iniciativa legislativa pretende estabelecer que, se o relator (e, quando for o caso, o revisor) tiver proferido seu voto e ocorrer algum pedido de vistas, necessariamente o processo deverá ser reapresentado para ser julgado no prazo equivalente a cinco sessões.

Ocorrerá, portanto, a conciliação e a ponderação entre a razoável duração do processo e a evidente necessidade de, em alguns casos, o julgador pretender acercar-se de maior cuidado para proferir seu voto.

Outro importante aspecto é que tal decisão acontecerá tanto para o Processo Penal quanto para o Processo Civil.

Cuida-se de iniciativa legislativa que pretende, assim, tornar mais célere o julgamento de processos, sem olvidar a necessidade da existência do duplo grau de jurisdição.

\section{Revisão dos recursos no CPP}

\section{Anteprojeto de Lei}

Altera os arts. $600, \S 44^{\circ}, 609,613,620,647,652,664$, todos do Código de Processo Penal e acrescenta o art. 638-A, também ao Código de Processo Penal, no intuito de melhorar a eficiência da Justiça a partir da revisão dos recursos cabíveis.

$[\ldots]$

Justificativa

O principal gargalo para a eficiência da justiça criminal e o enfrentamento à corrupção é o anacrônico sistema recursal brasileiro. 
Tal como reconhecido pelo então Presidente do STF, Ministro Cezar Peluso, em entrevista concedida ao jornal O Estado de S. Paulo no dia 22 de dezembro de 2010, “o Brasil é o único país do mundo que tem na verdade quatro instâncias recursais". É certo que esta ampla e quase inesgotável via recursal tem sido utilizada, na maioria das vezes, para protelar a marcha processual e evitar o cumprimento da lei. Daí a importância de que as condutas tendentes a prejudicar a celeridade e a efetividade da prestação jurisdicional sejam neutralizadas, sobretudo nos tribunais, onde o exame da prova já se encontra exaurido.

De fato, estudo da morosidade judicial promovido pelo Banco Mundial, publicado em 2003, destaca como uma das causas da morosidade o emprego de táticas protelatórias que beneficiam quem as emprega. Ressalta ainda o amplo reconhecimento de brechas da legislação processual brasileira, as quais permitem métodos protelatórios, propiciando oportunidades para que o réu escape da justiça. Como uma das soluções propostas para a sobrecarga do sistema judicial brasileiro, está o aumento da efetividade judicial.

Apesar das metas estabelecidas pelo $\mathrm{CNJ}$, a grande possibilidade de manuseio desarrazoado de recursos emperra a efetiva prestação jurisdicional. Em reportagem de maio de 2014, o jornal O Globo noticiou estudo da Fundação Getulio Vargas em que fora avaliado o tempo de tramitação das ações no Supremo Tribunal Federal, chegando-se à conclusão de que o principal motivo de lentidão é o volume de recursos. Veja-se (http://oglobo.globo. com/brasil/lentidao-suprema-stf-leva-em-media-cinco-anos-para-julgar-acoes-que-ferem-constituicao-12525704\#ixzz3NISSiyDR):

Entre os motivos para o quadro de lentidão, o grande volume de recursos que tomam o tempo do STF é apontado como o principal. A chamada repercussão geral foi um dos instrumentos criados pela emenda 45 para diminuir esse volume, diz Ayres Britto. Com ele, o STF só aceita recursos extraordinários de temas "que ultrapassem os interesses subjetivos da causa".

Mas esse instrumento poderia ser mais usado pela Corte. Até 9 de maio, dos casos com repercussão geral reconhecida, mais da metade $(65,7 \%)$ estava com julgamento do mérito pendente. E, dos casos com julgamento pendente, só 14,07\% foram incluídos em pauta; 83,53\% estão conclusos ao relator; e há 2,4\% "iniciados".

Outra tentativa de diminuir o número de recursos foi feita pelo exministro Cezar Peluso, autor da PEC 15/2011, que dizia que decisões de 
segunda instância seriam definitivas. Mas foi alterada em comissão do Senado em 2013. Agora, aguarda votação.

É evidente o espaço e a tentação que as táticas protelatórias representam no processo penal. A sobrecarga de processos em tribunais superiores faz com que o simples despacho de uma petição demore muito. Um estudo da FGV de 2014, por exemplo, revelou que o tempo médio para uma decisão, quando os autos vão conclusos, é de 154 dias, sendo de 54 dias em matéria processual penal e de 64 dias em matéria penal. Após a decisão, o tempo médio de publicação de acórdãos é de 167 dias, sendo de 197 dias em casos de direito penal. Somando tempo de decisão e tempo de publicação de acórdão, decorrem em média 261 dias em matéria penal, isto é, mais de meio ano. Bastam três petições clamando por decisões, como embargos de declaração, para que o feito se arraste por dois anos. $\mathrm{O}$ fato de que o decurso do tempo, na seara penal, conduz à prescrição, aliado à demora natural dos feitos, gera um ambiente que estimula o emprego de táticas protelatórias.

Uma das consequências da demora recursal é a impossibilidade de o Brasil repatriar centenas de milhões de reais desviados pela corrupção e que se encontram bloqueados no exterior, pois os demais países só costumam entregar os valores ao país de origem quando há uma decisão definitiva, com trânsito em julgado. É difícil até, no trato diário, que as autoridades estrangeiras compreendam que a decisão final poderá demorar, no Brasil, mais de quinze anos. No Caso Merchants, por exemplo, os Estados Unidos exigiram relatórios trimestrais do andamento dos feitos que embasaram bloqueios efetivados há mais de dez anos.

Passados mais de vinte anos desde a promulgação da Constituição de 1988, urge sedimentar políticas legislativas que promovam a celeridade processual e coíbam o uso abusivo de recursos, de forma que, preservados os direitos e as garantias individuais, seja também assegurada ao jurisdicionado a garantia de "razoável duração do processo", na feliz expressão da Emenda Constitucional no 45/2004. Se, por um lado, não é possível admitir a violação do direito de defesa no processo sumário, tampouco se pode tolerar a morosidade da prestação jurisdicional.

Um exemplo positivo do enxugamento das instâncias recursais decorre da nova sistemática adotada em torno da Lei da Ficha Limpa, que considera inelegíveis os condenados em virtude da prática de crimes graves, por decisão de órgão judicial colegiado, mesmo quando ainda não esgotada a via recursal. 
É certo que o duplo grau de jurisdição, entendido como garantia de revisão dos atos jurisdicionais, é um importante princípio do Estado de Direito e, como tal, é recomendável sua integração nos ordenamentos jurídicos democráticos. A garantia individual de ver uma decisão judicial revista por órgão judicial diverso e hierarquicamente superior, porém, não pode ser vista como um direito infinito ao recurso, a serviço da ineficiência do sistema processual penal.

É nesse contexto, pois, que se colocam as modificações legislativas propostas. Elas não maculam, sob nenhum aspecto, as garantias constitucionais inerentes ao devido processo legal e à ampla defesa, na medida em que se mantém hígido o direito das partes à produção de provas em seu favor, perante um juiz imparcial com competência previamente delimitada; não restringe o direito à assistência por advogado ou à apresentação de razões recursais; nem restringe o direito daquele que, não vendo sua demanda acolhida pelo tribunal, submete a matéria aos tribunais superiores. O procedimento em primeiro grau, aliás, não sofre praticamente nenhuma alteração.

A supressão do $\S 4^{\circ}$ do art. 600 é proposta porque, não raramente, após o protesto pela apresentação de razões em segundo grau, o apelante, intimado para esse fim na instância recursal, deixa de fazê-lo, o que gera a necessidade de nova intimação pessoal do acusado, por vezes via carta de ordem. Embora a medida não pareça acarretar grande atraso, fato é que, em decorrência da grande quantidade de feitos em trâmite nas diversas esferas do Judiciário, pode efetivamente procrastinar o trâmite recursal por meses, enquanto são diligenciadas a localização e a intimação pessoal do acusado na instância de origem.

Assim, a revogação do $\S 4^{\circ}$ do art. 600 do CPP é medida necessária, que traria impactos positivos no trâmite dos recursos e, por outro lado, nenhum prejuízo significativo às partes, já que remanescem os prazos para apresentação das razões na instância recorrida.

Outrossim, segundo o vigente Código de Processo Penal, quando a decisão em segunda instância não for unânime em desfavor do acusado, cabem embargos infringentes e de nulidade. Entretanto, a amplitude dos embargos infringentes e de nulidade tem causado embaraços à duração razoável do processo. Para evitar uma prodigalização excessiva dos embargos infringentes, em prejuízo da celeridade processual, a proposta reduz o seu cabimento ao âmbito realmente importante, admitindo a sua interposição para conferir ao acusado a oportunidade de fazer prevalecer em seu favor voto vencido pela absolvição. Assim, havendo, no órgão colegiado de segunda instância, 
voto vencido pela absolvição, o acusado remanesceria com a possibilidade de manejar os embargos infringentes.

Questão também relevante diz respeito aos embargos de declaração, que, não raro, servem a propósitos meramente protelatórios. Veja-se, por exemplo, o caso dos Embargos de Declaração nos Embargos de Declaração nos Embargos de Declaração no Agravo Regimental no Agravo de Instrumento n- 752.247/PR, Relator Ministro Joaquim Barbosa, un., j. 22/5/2012, DJe-112, de 23/5/2012. Na ocasião, o réu condenado pela prática de crime interpôs recurso extraordinário cujo seguimento foi negado pelo Tribunal recorrido. Interpôs agravo de instrumento destinado ao Supremo Tribunal Federal, que houve por bem denegá-lo, depois um agravo regimental e três embargos de declaração sucessivos, até que o Supremo Tribunal determinou que fosse certificado o trânsito em julgado do feito, independentemente da interposição de novos recursos.

A proposta de alteração da disciplina dos embargos de declaração visa coibir sua utilização com intuito protelatório, estabelecendo, à luz do vigente artigo 265 do Código de Processo Civil, a imposição de multa passível de adequação à gravidade do abuso processual.

Para ganhar tempo no trâmite recursal, o novo art. 638-A estabelece a simultaneidade dojulgamento dos recursos extraordinário e especial em matéria criminal. Hoje, quando são oferecidos recursos especial e extraordinário após o julgamento da apelação, os autos são remetidos ao Superior Tribunal de Justiça para o julgamento do recurso especial, e apenas depois do julgamento dele é que os autos seguirão para o Supremo Tribunal Federal. Isso faz com que o tempo de julgamento nos dois tribunais seja cumulativo, quando não há óbice para a apreciação simultânea, já que as matérias submetidas a um e outro tribunal são diferentes. A proposta altera essa rotina, estabelecendo o julgamento em paralelo nas duas instâncias, o que economizará anos no trâmite processual. Em prol da eficiência, a proposta inova ao criar um canal eletrônico de comunicação entre os tribunais para que um comunique ao outro o resultado do julgamento quando pender recurso neste último. Por fim, é inserida a suspensão dos prazos prescricionais, o que é uma cópia da proposição contida no §3o do art. 505 do Projeto 8.045/2010, de um novo CPP.

Noutro giro, as alterações sugeridas para o habeas corpus visam evitar que, em instrumento moldado para proteção da liberdade ambulatorial, sejam adotados, por exemplo, expedientes destinados a anular processos de forma açodada; e, por outro lado, compatibilizar sua regência com os princípios previstos no artigo 157 do Código de Processo Penal. 
Por fim, cabe uma ressalva. As causas da morosidade na tramitação das ações e recursos não se resumem à regulamentação do procedimento recursal. Não se ignora que uma série de fatores estruturais, econômicos, políticos e sociológicos também tem papel relevante na lentidão dos processos. No entanto, a existência de outros fatores não justifica que não se resolvam os problemas decorrentes de incongruências do procedimento recursal; pelo contrário, deve-se ao máximo implementar os meios necessários para assegurar a viabilização do interesse social na responsabilização dos autores de crimes e o direito constitucional do réu e da sociedade de se valer de procedimento judicial célere para tanto.

\section{Execução provisória da pena}

\section{Anteprojeto de Emenda Constitucional}

Altera o art. 96 da Constituição da República Federativa do Brasil para incluir o parágrafo único, bem como acrescenta o $\S^{\circ}{ }^{\circ}$ ao art. 102 e o artigo 105-A, da Constituição Federal.

\section{Justificativa}

Segundo dados da Assessoria de Gestão Estratégica do STF, entre 2009 e 2010, foram interpostos 5.300 recursos extraordinários criminais e agravos de instrumento em matéria criminal, o que equivale a $8 \%$ do total do período. Destes, apenas 145 foram providos. Esse índice representa apenas 0,22\% do total de recursos extraordinários interpostos no STF em 2009 e 2010. Ainda há que se considerar que, desses 145 recursos, 77 foram providos em favor do Ministério Público e 59 tratavam de execução criminal. Ou seja, apenas 9 (nove) recursos extraordinários criminais foram julgados e providos pelo STF em prol da defesa, antes do trânsito em julgado da condenação. Em apenas um (!) desses RE o STF veio a absolver o réu.

Daí, importante retirar o efeito suspensivo dos RE e dos RESP, por alteração constitucional sugerida, tal como era antes de o STF decidir a questão no HC 84.078/MG. Seria o retorno à lógica sistêmica, presente nos ordenamentos do direito comparado e harmônica com as convenções de direitos humanos, que traria de volta a racionalidade do modelo recursal, de modo a privilegiar 
as instâncias ordinárias, sem prejudicar o direito ao duplo grau e sem tolher a possibilidade de o réu interpor recurso especial ou recurso extraordinário ou, ainda, impetrar habeas corpus, para romper acórdãos abusivos proferidos por cortes regionais federais ou pelos tribunais de Justiça dos Estados.

Outrossim, o Conselho da Europa, organização pan-europeia que congrega 47 países daquele continente, aprovou em 1995 a Recomendação

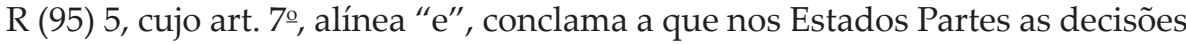
da jurisdição cível e comercial proferidas por tribunais de segundo grau sejam imediatamente executáveis, salvo se esse mesmo tribunal ou uma corte superior (third court) determinar a suspensão da execução, ou se o apelante prestar garantias à execução. (Decisions made by the second court should be enforceable, unless the second or the third court grants a stay of execution or the appellant gives adequate security.)

Se não bastasse, a garantia da duração razoável do processo e "dos meios que garantam a celeridade de sua tramitação" não se restringe ao processo civil; é também do processo penal e, neste, não é patrimônio apenas dos acusados, mas também das vítimas e da sociedade. $\mathrm{O}$ direito fundamental protegido pelas convenções internacionais de direitos humanos, como o Pacto de São José da Costa Rica, o Pacto Internacional sobre Direitos Civis Políticos e a Convenção Europeia de Direitos Humanos, restringe-se à observância do duplo grau, isto é, ao julgamento justo e imparcial em primeira instância e ao reexame com as mesmas qualidades, por um órgão colegiado superior. Não existe garantia constitucional, convencional ou legal ao quádruplo grau, ou ao reexame sem fim, que suportaria um fantasioso direito fundamental à prescrição, que muitos pensam ler no inciso LV da nossa Constituição.

\section{Medida 5}

\section{Maior eficiência da Ação de Improbidade Administrativa}

\section{Procedimento para agilizar a tramitação da AIA}

\section{Anteprojeto de Lei} de junho de 1992, para agilizar a tramitação da ação de improbidade administrativa. 
Justificativa

As alterações propostas nos aludidos dispositivos do art. 17 da Lei no 8.429 , de 2 de junho de 1992, buscam implementar melhorias no rito procedimental relacionado às ações de improbidade administrativa, a fim de superar uma das principais causas responsáveis pela notória morosidade na tramitação dessas ações.

Pretende-se, com efeito, a extinção da esdrúxula fase de notificação preliminar e recebimento da ação de improbidade administrativa.

A Lei da Improbidade Administrativa teve como um de seus objetivos criar um mecanismo judicial célere que permitisse a responsabilização de natureza cível e administrativa com relação a agentes públicos que praticaram ou tentaram praticar atos ímprobos.

No entanto, ultrapassados mais de vinte anos desde a edição da Lei no 8.429/1992, o que se tem é um excessivo e irrazoável rigor procedimental no processo de sancionamento por atos de improbidade administrativa, ao passo que o processo penal - o qual tutela bem jurídico ainda mais importante para o indivíduo (a liberdade) - tornou-se mais ágil do que o processo civil correspondente (ao menos no que se refere à tramitação das ações penais em primeiro grau de jurisdição).

A morosidade na tramitação das ações de improbidade administrativa é nefasta a ponto de o Conselho Nacional de Justiça (CNJ), órgão de controle externo do Poder Judiciário, estabelecer a meta das Justiças Estadual, Federal e Militar, além do Superior Tribunal de Justiça, para “identificar e julgar, até 31/12/2013, as ações de improbidade administrativa e ações penais relacionadas a crimes contra a administração pública distribuídas até 31/12/2011" (Meta 18, de 2013).

No entanto, as metas estabelecidas pelo CNJ ficaram longe de alcançar o efeito desejado. Mesmo com os esforços concentrados realizados por juízes, pelo país afora, o Relatório de Metas Nacionais do Poder Judiciário 20092013 revelou que nenhum Tribunal do país logrou alcançar a meta. Segundo as informações prestadas pelos Tribunais, até 31 de dezembro de 2011, havia, no Poder Judiciário, um estoque de 43.773 ações de improbidade distribuídas e não julgadas. Mesmo com os esforços impostos pela Meta 18, de tais ações somente 10.643 foram julgadas no ano de 2012, e apenas outras 9.864 no ano de 2013.

Vê-se, portanto, que o problema da morosidade na tramitação dessas ações não será resolvido apenas com esforços concentrados e priorização de julgamentos. Para tanto, é necessário identificar os fatores que realmente 
influenciam na dificuldade de tramitação desses processos, bem como criar meios para destravá-los.

O primeiro obstáculo procedimental à celeridade das ações de improbidade administrativa é, sem dúvida, a fase de notificação preliminar e recebimento da ação, antes mesmo da citação do réu.

Dito procedimento, criado pela Medida Provisória nº 2.225-45, de 2001, tinha a intenção declarada de possibilitar um contraditório prévio, a fim de evitar a tramitação de ações consideradas temerárias. Assim, pretendia-se conferir ao julgador a oportunidade de, antes mesmo de admitir ou não a tramitação do processo, conhecer os argumentos de defesa do réu e deliberar pelo não recebimento da ação, quando convencido liminarmente da inexistência do ato de improbidade, da improcedência da ação ou da inadequação da via eleita.

Ocorre, desafortunadamente, que a MP nº 2.225/2001 acabou por criar a necessidade de uma dupla notificação/citação do réu já que, após a notificação preliminar e a decisão sobre o recebimento da ação, ainda se faz necessária a citação pessoal do réu.

Na prática, isso implica que o réu deverá ser intimado pessoalmente duas vezes: a primeira, para se manifestar sobre os termos da ação, e a segunda, para contestá-la. Não há, entretanto, diferença substancial entre as defesas da primeira notificação e da segunda citação; em regra, há a mera repetição da peça uma vez que o réu pode, já na manifestação preliminar, apresentar toda a matéria de defesa de fato e de direito, na tentativa de convencer o julgador a rejeitar liminarmente a ação.

Esse procedimento esdrúxulo constitui verdadeiro obstáculo à celeridade na tramitação das ações de improbidade administrativa porque os dois atos notificação preliminar e citação - devem ser dirigidos à pessoa do réu, não se podendo sequer fazê-lo pelo advogado constituído. É comum que, após diversas tentativas de localizar o réu para receber a notificação para manifestação preliminar, tais tentativas tenham que ser refeitas após o recebimento da ação, apenas para que o réu possa ser agora citado pessoalmente.

A situação é agravada quando há diversos réus na ação, já que o recebimento da inicial somente poderá ocorrer após a notificação preliminar de todos eles. Muitas vezes, a citação somente vem a ocorrer anos após a primeira notificação, quando o réu já mudou seu endereço.

Ainda deve-se levar em consideração que, no governo federal e nos governos estaduais, é extremamente comum que os detentores de cargos de direção sejam requisitados de outros órgãos ou deslocados de outras lotações 
para o exercício daquele cargo, de forma que essas pessoas mudam de endereços constantemente. Com a necessidade de dupla notificação/citação, em regra não se logra localizar o réu no mesmo endereço da primeira notificação.

As consequências terríveis desse procedimento para a tramitação das ações de improbidade administrativa ficam ainda mais evidentes diante de casos concretos que demonstram a verdadeira paralisação dos processos em razão dessas dificuldades.

Veja-se a ação de improbidade administrativa relacionada ao caso do Projeto Correio Híbrido Postal, um dos desdobramentos do famigerado esquema de fraudes nas licitações dos Correios, envolvendo, dentre outros, Maurício Marinho, que ganhou notoriedade nacional a partir da divulgação de registro de vídeo em que recebia propina.

A ação, com sete réus, foi proposta em 29 de julho de 2010. A fase de notificação preliminar dos réus somente foi concluída em julho de 2013, ou seja, três anos depois da propositura da ação. Em seguida, em 12 de novembro de 2013 foi proferida a decisão de recebimento da petição inicial e ordenada a realização da citação dos réus. Desde então, decorrido bem mais de um ano desde a decisão de recebimento, o processo ainda se encontra na fase de citação.

Ressalta-se que o ato de comunicação processual que está sendo realizado nesta fase - a citação - não é essencialmente diferente do ato de notificação, pois ambos visam dar conhecimento ao réu do teor da acusação formulada e permitir a defesa.

Ou seja, nesta ação foram necessários três anos apenas para que fosse concluída a fase de notificação preliminar dos réus e, na fase seguinte, mais um ano já foi consumido apenas para renovar a comunicação processual, não sendo possível prever quando, finalmente, se iniciará a fase de instrução do processo.

Diga-se, mais ainda, que muito provavelmente os réus terão o trabalho único de renovar as linhas de argumentação já oferecidas por ocasião da defesa preliminar, em um verdadeiro faz de conta procedimental no qual o único perdedor é o Princípio da Razoável Duração do Processo, estabelecido no art. 5ํ, LXXVIII, da Constituição.

O caso aludido não é isolado. Uma simples pesquisa da tramitação das ações no Poder Judiciário permite identificar diversos outros processos nos quais a marcha processual das ações de improbidade administrativa foi atrasada em alguns anos, diante da fase de dupla notificação/citação dos réus.

Nessa linha, os mesmos percalços sofreu a ação em face de dirigentes da FUB (Fundação Universidade de Brasília) e do CESPE (Centro de Seleção e 
Promoção de Eventos da UnB, responsável pela realização de boa parte dos concursos do país), proposta em razão de burla à Lei de Licitações e do desvio de recursos para empresas cujos sócios tinham vínculos com dirigentes do CESPE.

A ação, com sete réus, foi proposta em 15 de outubro de 2008. A fase preliminar somente foi concluída quatro anos após, com o recebimento da ação em 6 de novembro de 2012. Em seguida, foi necessário aguardar mais um ano e meio para a renovação das citações, e a instrução processual somente foi realmente desencadeada em julho de 2014, com o despacho que determinou às partes a indicação das provas a serem produzidas.

Outros tantos atos de improbidade administrativa acabam por ter a mesma sina: embora a investigação identifique graves atentados ao erário e aos princípios da Administração Pública, a efetiva aplicação de penalidades acaba por ser prejudicada em razão do distanciamento temporal entre o julgamento e a acusação, que no caso é consubstanciada pela propositura da ação.

Para sanar esse problema, pretende-se trazer para a ação de improbidade administrativa um rito de recebimento semelhante ao que foi implementado para o processo penal, pela Lei no 11.719 , de 20 de junho de 2008. A reforma instituída por esse diploma modificou o Código de Processo Penal para criar uma fase de análise preliminar da (in)viabilidade da acusação que é realizada, no entanto, após a citação do réu.

Com a instituição de um momento único de citação do réu, seguido de uma análise preliminar sobre a viabilidade da ação, entende-se que se está contemplando tanto a preocupação que deu origem à fase de dupla notificação/citação criada pela MP nº 2.245/2001 (evitar a tramitação de ações temerárias) quanto a necessidade de agilizar a tramitação do processo judicial mediante a extinção da desnecessária duplicidade de notificação pessoal para instauração do processo.

Nessa linha, a jurisprudência tem entendido que o procedimento criado pela Lei no $11.719 / 2008$, na esfera processual penal, suplantou até mesmo o procedimento de notificação preliminar do funcionário público previsto no art. 514 do Código de Processo Penal, uma vez que é mais democrático e, ao mesmo tempo, respeita o contraditório prévio.

De fato, veja-se o entendimento exposto pelo Ministro Celso de Mello, do Supremo Tribunal Federal (HC no 115441/MT):

[...] a reforma processual penal estabelecida por legislação editada em 2008 revelou-se mais consentânea com as novas exigências estabelecidas pelo moderno processo penal de perfil democrático, cuja natureza 
põe em perspectiva a essencialidade do direito à plenitude de defesa e ao efetivo respeito, pelo Estado, da prerrogativa ineliminável do contraditório.

Bem por isso, a Lei no 11.719/2008, ao reformular a ordem ritual nos procedimentos penais, instituiu fase preliminar caracterizada pela instauração de contraditório prévio, apto a ensejar, ao acusado, a possibilidade de arguir questões formais, de discutir o próprio fundo da acusação penal e de alegar tudo o que possa interessar à sua defesa, além de oferecer justificações, de produzir documentos, de especificar as provas pretendidas e de arrolar testemunhas, sem prejuízo de outras medidas ou providências que repute imprescindíveis.

Com tais inovações, o Estado observou tendência já consagrada em legislação anterior, como a Lei no 10.409/2002 (art. 38) e a Lei no 11.343/2006 (art. 55), cujas prescrições viabilizaram a prática de verdadeiro contraditório prévio no qual o acusado poderia invocar todas as razões de defesa - tanto as de natureza formal quanto as de caráter material.

Tenho por relevante, por isso mesmo, esse aspecto da questão, uma vez que o magistrado federal de primeiro grau, no caso em exame, ordenou a citação do denunciado, ora paciente, para que oferecesse resposta à denúncia do Ministério Público Federal, ensejando, assim, a possibilidade do contraditório prévio a que se referem os arts. 396 e 396-A do Código de Processo Penal, o que afasta a alegação de prejuízo para a defesa do acusado.

É que, tal como anteriormente enfatizado, esse novo modelo ritual tornou lícita a formulação, em mencionada resposta prévia, de todas as razões, de fato ou de direito, inclusive aquelas pertinentes ao mérito da causa, reputadas essenciais ao pleno exercício da defesa pelo acusado, como assinala, com absoluta correção, o magistério da doutrina (EUGÊNIO PACELLI DE OLIVEIRA e DOUGLAS FISCHER, "Comentários ao Código de Processo Penal e sua Jurisprudência", p. 869/870, 2a ed., 2011, Lumen Juris; PEDRO HENRIQUE DEMERCIAN e JORGE ASSAF MALULY, “Curso de Processo Penal”, p. 374/375, 4a ed., 2009, Forense; ANDREY BORGES DE MENDONÇA, "Nova Reforma do Código de Processo Penal”, p. 260/264, 2ª ed., 2009, Método, v.g.).

Conclui-se que, se o objetivo da fase de notificação preliminar e do recebimento da ação de improbidade administrativa é oportunizar o contraditório prévio e evitar a tramitação de ações temerárias, encontra-se ele integralmente 
atendido pelo estabelecimento de uma fase de análise preliminar da viabilidade da ação após a citação, tal como previsto na aludida reforma do Código de Processo Penal, daí que se mostra absolutamente desnecessário e prejudicial ao trâmite da ação proceder a duas notificações pessoais, uma antes e outra após a decisão de recebimento.

A modificação ora pretendida, portanto, exclui do rito procedimental da ação de improbidade administrativa o arcaico procedimento de notificação preliminar, de recebimento e de citação pessoal, o qual contribui, em larga escala, para a morosidade do processo judicial de responsabilização e, em última análise, para a impunidade em razão da inefetividade jurídico-social do instituto como meio de combate à corrupção.

Registre-se que a redação proposta procurou manter os termos já utilizados pela legislação atual, ainda que de técnica imprecisa, como forma de evitar que alterações terminológicas suscitem novas dúvidas sobre a aplicação do novo procedimento.

Diga-se, por fim, que o $§ 10$ do art. 17 da Lei no 8.429/1992 recebeu novo teor, à semelhança do que já ocorre no art. 238, parágrafo único, do Código de Processo Civil, adequando-se este último dispositivo aos ditames pretendidos pela alteração legislativa ora proposta.

\section{Varas especializadas}

\section{Anteprojeto de Lei}

Prevê a criação de Turmas, Câmaras e Varas Especializadas para o julgamento das ações relativas a atos de improbidade administrativa, no âmbito dos Tribunais Regionais Federais e os Tribunais de Justiça dos Estados e do Distrito Federal e Territórios, e dá outras providências.

\section{Justificativa}

A presente iniciativa legislativa possui a finalidade primordial de agilizar a tramitação das ações de improbidade administrativa com a criação de Turmas, Câmaras e Varas Especializadas em seu julgamento.

Assim ocorre em razão da experiência exitosa, no Direito Brasileiro, das Varas Criminais Especializadas para o julgamento de crimes de lavagem de dinheiro e contra o sistema financeiro nacional. 
Em uma vara com atribuição cível universal, o julgador tem, em seu acervo, milhares de ações com os mais variados temas e ritos. A título ilustrativo, consoante estatísticas publicadas pelo Conselho da Justiça Federal, em 2013, havia um estoque médio de 8.757 processos aguardando julgamento por Vara Federal no Distrito Federal.

A sistemática atual de distribuição de ações judiciais não contempla qualquer diferenciação entre uma ação de improbidade administrativa e algum outro processo repetitivo, a exemplo de mandados de segurança que envolvem questões tributárias. Assim, para fins estatísticos, não há diferenciação entre proferir uma sentença em um processo comum, em um mandado de segurança ou em uma ação de improbidade administrativa.

Ocorre que, ordinariamente, o julgamento de uma ação de improbidade administrativa demanda da autoridade julgadora mais tempo e maior esforço intelectivo do que o julgamento de outros processos mais simples ou de matéria repetitiva.

De fato, considerando-se a necessidade de revirar extensa matéria de fato e de direito e a responsabilidade de proferir julgamento sobre direitos fundamentais dos acusados, cada ação de improbidade administrativa demanda muito mais do julgador do que outros processos com matérias mais corriqueiras e de natureza exclusivamente patrimonial.

Diante disso, natural que o julgador, premido pela necessidade de diminuir o gigantesco estoque de procedimentos à espera de julgamento, dê preferência aos processos simples e corriqueiros, deixando de lado a tramitação de processos mais complexos, como as ações de improbidade administrativa.

A morosidade na tramitação das ações de improbidade administrativa é nefasta a ponto de o Conselho Nacional de Justiça (CNJ), órgão de controle externo do Poder Judiciário, estabelecer a meta das Justiças Estadual, Federal e Militar, além do Superior Tribunal de Justiça, para “identificar e julgar, até 31/12/2013, as ações de improbidade administrativa e ações penais relacionadas a crimes contra a administração pública distribuídas até 31/12/2011" (Meta 18, de 2013).

No entanto, as metas estabelecidas pelo $\mathrm{CNJ}$ ficaram longe de alcançar o efeito desejado. Mesmo com os esforços concentrados realizados por juízes, pelo país afora, o Relatório de Metas Nacionais do Poder Judiciário 20092013 revelou que nenhum Tribunal do país logrou alcançar a meta. Segundo as informações prestadas pelos Tribunais, até 31 de dezembro de 2011, havia, no Poder Judiciário, um estoque de 43.773 ações de improbidade distribuídas e não julgadas. Mesmo com os esforços impostos pela Meta 18, de tais ações 
somente 10.643 foram julgadas no ano de 2012, e apenas outras 9.864 no ano de 2013.

Vê-se, portanto, que o problema da morosidade na tramitação dessas ações não será resolvido apenas com esforços concentrados e priorização de julgamentos. Para tanto, é necessário identificar os fatores que realmente influenciam na dificuldade de tramitação desses processos, bem como criar meios para destravá-los.

Nesse sentido, uma das possíveis soluções reside na criação de Turmas, Câmaras e Varas Especializadas para o julgamento de ações de improbidade administrativa.

O que se pretende, portanto, é o estabelecimento de uma opção legislativa para priorizar as ações de improbidade administrativa, ao invés de deixar a cargo de cada julgador a difícil escolha entre sentenciar uma ação complexa ou dezenas de ações simples e repetitivas.

Esse foi o modelo implantado nas já mencionadas Varas Criminais Especializadas para julgar crimes de lavagem de dinheiro e contra o sistema financeiro nacional, o qual vem se mostrando exitoso e de acordo com o princípio constitucional da razoável duração do processo, e também por isso foi elencado dispositivo no sentido de autorizar que ditas Varas Especializadas julguem os crimes decorrentes da menção aos atos ímprobos descritos, por meio da ação penal respectiva.

Aproveitou-se a oportunidade para incluir, no âmbito da especialização, as ações judiciais cíveis decorrentes da Lei Anticorrupção (Lei no ${ }^{-12.846}$, de 1/8/2013), em decorrência da similitude quanto ao seus objeto e finalidade, bem como se autorizou ao Superior Tribunal de Justiça que crie Turma específica voltada ao julgamento desse tipo de ação.

É certo que as causas da morosidade na tramitação das ações de improbidade administrativa seguramente não se resumem a esse aspecto procedimental. Não se ignora que uma série de fatores políticos e sociológicos também possuem relevante papel na lentidão dessas ações, uma vez que não raramente essas causas interferem em poderosos interesses econômicos e políticos e dizem respeito a réus que detêm influência social e meios financeiros para dificultar o andamento do processo judicial.

No entanto, a existência de outros fatores não justifica que não se resolvam os problemas decorrentes de incongruências procedimentais e estruturais; pelo contrário, deve-se ao máximo implementar os meios necessários para que o processo sirva para assegurar a viabilização do interesse social na responsabilização dos autores de atos ímprobos e o direito constitucional da sociedade de se valer de procedimento judicial célere para tanto. 


\section{Acordo de leniência}

\section{Anteprojeto de Lei}

Acresce o art. 17-A à Lei no 8.429, de 2 de junho de 1992, para disciplinar o acordo de leniência.

$[\ldots]$

\section{Justificativa}

O Brasil dispõe de arsenal legislativo voltado ao combate à corrupção, nas diversas esferas de responsabilidade (criminal, civil, administrativa e política), podendo-se afirmar a existência de um verdadeiro microssistema anticorrupção.

Assim é que um único fato pode deflagrar a instauração de diversas esferas de responsabilidade, possibilitando a aplicação de sanções criminais, cíveis, administrativas e políticas sem que se incorra na vedação do bis in idem.

Como todo microssistema - organismo normativo menor, dentro do sistema jurídico maior - , hão de ser garantidas a integridade, a coerência e a previsibilidade dos seus institutos, fazendo com que as diversas esferas de responsabilidade conversem entre si e permitam uma aplicação de onde se possa retirar o máximo de efetividade da norma com o maior grau de segurança jurídica possível.

É nesse cenário que se vislumbra a necessidade de regulamentação do acordo de leniência no âmbito da Lei de Improbidade Administrativa, dando maior previsibilidade e segurança ao investigado no campo da dimensão premial do direito sancionador.

Uma das modernas técnicas especiais de investigação (TEI), utilizada no mundo inteiro, consiste nos acordos de colaboração premiada ou de leniência, em que o investigado se dispõe a esclarecer todo o esquema de corrupção e a apontar os demais envolvidos e os elementos de prova dos ilícitos praticados, em troca de benefício (prêmio) para reduzir o impacto de suas sanções ou, mesmo, ficar imune em relação a elas.

Tal técnica de investigação não apenas acelera a resolução do caso, como também evita injustiças, já que ninguém melhor do que um coautor da infração, tendo-a vivenciado, para esclarecer os fatos, a estrutura da organização criminosa, o modus operandi, bem como para apontar o caminho das provas. 
Nesse sentido, quanto ao risco de colaborações mentirosas para ganho indevido de benefício ou retaliação de outras pessoas, há as regras de segurança do instituto, a saber, a corroboração (confirmação do depoimento do colaborador com outros elementos de prova, não valendo o depoimento em si como meio de prova) e a possibilidade de rescisão do acordo em casos de manipulação da verdade, má-fé ou reincidência na prática infracional.

Não foi por outra razão que em dois dos maiores escândalos noticiados no Brasil e investigados por meio da Operação Lava-Jato e da Operação Ararath, sob o controle e supervisão do Ministério Público Federal, houve o desbaratamento de organizações criminosas com o auxílio da colaboração premiada, cujo resultado se mostrou mais eficaz para a colheita de provas que o antigo método, bastante utilizado nas investigações criminais, da interceptação telefônica.

Isso porque a colaboração premiada não só explica a inteligência das provas já colhidas, mas uma das obrigações do colaborador é a de fornecer meios de prova para a autoridade competente ou, no mínimo, indicar o caminho onde as evidências podem ser recolhidas.

No microssistema brasileiro de combate à corrupção há previsão expressa de acordo de colaboração premiada na esfera criminal (Leis n 오 9.034/1995, 9.613/1998, 9.807/1999 e mais recentemente a Lei no ${ }^{12.850 / 2013), ~ n o ~ a ̂ m b i t o ~}$ das infrações contra a ordem econômica (Lei no $12.529 / 2011$ ) e na Lei Anticorrupção (Lei no 12.846/2013).

Já a esfera de responsabilização da improbidade administrativa, uma das mais importantes no combate à corrupção, não dispõe de um acordo de leniência próprio, explicitado em lei, disposto a entregar benefícios legais ao investigado que se dispõe a colaborar efetivamente com as autoridades competentes.

Dita lacuna acaba por gerar uma incoerência no sistema, pois um mesmo fato pode gerar consequências sancionadoras nas diversas instâncias, o que pode gerar um certo temor ao potencial colaborador de entregar provas em troca de benefício numa instância e se autoincriminar em outra instância em troca de nenhum prêmio.

É claro que, a partir do microssistema anticorrupção, é possível extrair a autorização normativa para se celebrarem acordos de colaboração no âmbito da improbidade administrativa, mas a ausência de norma expressa acaba inibindo o reporte espontâneo do investigado e diminuindo substancialmente o número de acordos celebrados nessa esfera de responsabilidade. 
Por essa razão, faz-se necessária a inserção legislativa de acordo de leniência na Lei de Improbidade Administrativa, com regras próprias e expressas quanto aos requisitos e benefícios em troca da efetiva colaboração.

O presente texto, inclusive, está em harmonia com a colaboração criminal (regulada detalhadamente pela Lei no 12.850/2013) e com o acordo de leniência da Lei Anticorrupção (Lei oํ 12.846/2013), a fim de fechar uma interlocução necessária e sem antinomias entre as diversas esferas de responsabilidade do nosso direito sancionador, e em observância às garantias constitucionais dos investigados.

Outro ponto que merece destaque diz respeito à legitimidade para a celebração de tais acordos de colaboração, pois, nesse aspecto, quanto maior o número de legitimados, maior será a insegurança jurídica, a alta exposição do investigado sobre os seus ilícitos, a diminuição da vontade de cooperar e a possibilidade de violação do sigilo.

Por essa razão, a competência para celebração do acordo de leniência na improbidade administrativa deve ficar restrita ao Ministério Público, órgão que tem legitimidade para o ajuizamento da ação por ato de improbidade administrativa e da ação penal pública por ato de corrupção, decorrente do mesmo fato.

Ampliar a competência para celebração de acordo de leniência para a pessoa jurídica lesada, que também tem legitimidade para o ajuizamento de ação de improbidade administrativa, acaba por expor indevidamente o investigado para duas instituições, pois esse ente não tem legitimidade para celebrar acordo de colaboração criminal e inevitavelmente tem o dever de compartilhar essas informações com o Ministério Público.

Há, também, o risco de acordos não condizentes com o interesse público serem firmados entre a pessoa jurídica lesada e o investigado, para o fim de beneficiá-lo, sem a devida adequação jurídica. Imagine-se, aqui, um prefeito, a mais alta autoridade do município, sendo investigado por improbidade. Acaso o acordo fosse realizado pela pessoa jurídica, quem estabeleceria as condições do acordo? O próprio investigado!

Daí a conveniência de o Ministério Público ser o titular exclusivo da proposta de acordo de leniência, na medida em que se coloca como Instituição que desempenha o controle externo da Administração Pública e que possui o distanciamento adequado para realizar acordos com mais isenção e proporcionalidade.

Entendemos, por fim, que a redação do item que trata do acordo de leniência está em harmonia com o microssistema anticorrupção e confere maior 
segurança jurídica aos próprios investigados, uma vez que, a partir de sua aprovação, haverá regras claras e garantistas para se exigir o seu fiel cumprimento e a fiscalização judicial dos demais investigados.

\section{Medida 6}

\section{Ajustes na prescrição penal contra a impunidade e a corrupção}

\section{Prescrição penal}

\section{Anteprojeto de Lei}

Altera os arts. 110, 112, I, 116 e 117 , e acrescenta $§ 2^{\circ}$ ao art. 337-B, todos do Decreto-Lei no 2.848, de 7 de dezembro de 1940 - Código Penal, que versam sobre o prazo prescricional penal.

\section{Justificativa}

No Brasil, o atual modelo de prescrição acaba sendo um dos principais fatores de impunidade nos crimes em geral e com ainda mais gravidade nos casos de crimes ditos "do colarinho-branco".

A criminalidade do colarinho-branco, abrangida popularmente pelo conceito de corrupção, acontece escondida, submersa em "conchavos", "negociatas" e outros expedientes ilícitos de ocultação. Ao contrário da criminalidade grave clássica (homicídios, p. ex.), em que há resultado exposto à sociedade (desaparecimentos etc.), na criminalidade grave moderna (desvios de dinheiro público, "achaques" etc.) os corruptores e corrompidos praticam o crime às escondidas e mantêm entre si um pacto de silêncio que tem duplo objetivo: garantir os benefícios buscados com o conluio e evitar a punição pelos crimes.

Além de estratégias de ocultação, criminosos de colarinho-branco, em geral, valem-se de esquemas criminosos complexos, envolvendo transações sofisticadas no sistema financeiro, remessas transacionais, lavagem de dinheiro terceirizada e internacional, emprego de documentos falsos etc. Isso tudo torna a investigação e o processamento de crimes de colarinho-branco, usualmente, uma tarefa bastante complexa, estendendo os procedimentos no tempo. 
Some-se que criminosos de colarinho-branco, como regra, podem contratar advogados com elevada qualidade técnica, e poderão arcar com os custos envolvidos para que sejam manejados todos os recursos possíveis e imagináveis, não só para obter decisões favoráveis, mas também porque, em nosso sistema, postergar implica, em grande parte dos casos, ganhar. A busca da prescrição e consequente impunidade é uma estratégia de defesa paralela às teses jurídicas, implicando o abuso de expedientes protelatórios.

Mesmo em casos que não são de colarinho-branco, o atual sistema prescricional representa uma tentação para que a defesa "ganhe" a causa mediante sua protelação, o que gera vários ônus econômicos ao sistema de justiça, como renovação de intimações, oitiva de testemunhas desnecessárias, inclusive por precatórias e rogatórias, análise de petições por vista, cópias, juntada de documentos ou substabelecendo poderes que têm por escopo precípuo alongar o caso, oferecimento de recursos repetitivos com abuso do direito de recorrer etc.

Uma consequência do sistema atual é que a parte autora, em causas criminais de colarinho-branco, é a única sancionada no processo penal. Ao invés de o criminoso ser punido, é a vítima quem sofre duas vezes, não só com o crime cometido, mas também com os custos econômicos e morais de um processo sem resultado prático. Mais ainda, a maior penalização é aquela que advirá da impunidade, consistente no estímulo à criminalidade e a novas violações dos bens jurídicos, "tutelados" pelas normas penais, mas deixados a descoberto por um sistema prescricional condescendente com a criminalidade.

De fato, autores consagrados no estudo da corrupção apontam a impunidade como um fator decisivo na escolha do agente entre praticar ou não a corrupção. De fato, tanto Rose-Ackerman como Klitgaad colocam a probabilidade da punição como um dos fatores decisivos avaliados pelo agente na análise da relação entre custo e benefício da prática da corrupção. Daí a importância de transformar nosso sistema punitivo disfuncional em um sistema de punições justas e efetivas, capaz de detectar, investigar e punir comportamentos desviados.

Mesmo a reforma do sistema recursal e a agilização dos trâmites da Justiça, sem a reforma do sistema prescricional, não mudariam esse cenário, pois crimes de colarinho-branco continuariam a ser complexos para investigar e processar, e continuaria a haver um incentivo ao emprego de estratégias defensivas para que os processos demorem, sobrecarregando a Justiça. A reforma proposta sobre o sistema prescricional entra nesse contexto. 
O interesse da sociedade é que os casos sejam solucionados e que a prescrição ocorra tão somente por falhas do Estado e não por estímulo dos delinquentes. Nesses termos, Fabio Guaragni (2008, p. 17) explica que:

As razões pelas quais se apresenta a prescrição penal como verdadeiro fator de impunidade, apartando-se de sua original missão de atuar em níveis razoáveis - em termos de política criminal - como causa extintiva de punibilidade, encontram-se tanto na própria sistemática em que está vazado, no Código Penal brasileiro, o instituto, quanto no excessivo liberalismo que caracteriza a jurisprudência nacional em temas de direito penal.

Recente levantamento feito pelo Conselho Nacional de Justiça (CNJ) demonstra que, entre 2010 e 2011, a Justiça brasileira deixou prescrever 2.918 ações envolvendo crimes de corrupção, lavagem de dinheiro e atos de improbidade administrativa. Todos esses atos ilícitos são reconhecidamente graves, por retirarem recursos do Estado que poderiam ser empregados para atender aos anseios da população por melhores serviços públicos, como exigência para uma cidadania mais ampla.

Até o final de 2012, tramitavam 25.799 processos de corrupção, lavagem de dinheiro ou atos de improbidade em todo o Poder Judiciário. Analisando os dados, constata-se que os processos prescritos somente em dois anos (2010 e 2011) representam mais de $11 \%$ dos feitos em andamento, o que não devia ser tolerado.

Uma das razões dessa pesquisa era responder aos questionamentos do Grupo de Ação Financeira Internacional (GAFI), que avaliou negativamente as medidas do Brasil para o combate desses delitos, mormente em decorrência da falta de estatísticas processuais. As estatísticas devem servir para subsidiar o país no processo de avaliação da implantação da Convenção das Nações Unidas contra a Corrupção (Uncac) e para cumprir Estratégia Nacional contra a Corrupção e a Lavagem de Dinheiro (Enccla), coordenada pelo CNJ.

Vamos à análise das modificações propostas. Em primeiro lugar, a alteração no artigo 110 objetiva extinguir a prescrição retroativa, que é um dos mais maléficos institutos peculiares ao direito penal pátrio, sendo uma das principais responsáveis pelo estímulo a táticas protelatórias.

Nesses termos, Fabio Guaragni ensina (2008, p. 126):

Em síntese, a prescrição retroativa pode ser atacada pela via da inconstitucionalidade, por não respeitar os princípios de certeza e utilidade 
dos prazos que, sendo corolários do princípio do devido processo legal, ex vi do art. 5o, LIV, se aplicam aos prazos prescricionais. [...] Numa palavra: a prescrição retroativa, importando na negação da existência do processo e da sentença penal condenatória, nega a existência de seus próprios pressupostos. É um contrassenso admitir que a sentença valha para, em última análise, implicar a sua própria inexistência e a condenação, uma vez quantificada, sirva por critério para estabelecer que no caso concreto não poderia haver condenação.

Vale observar que a Associação dos Juízes Federais do Brasil e a Associação dos Procuradores da República, ao menos desde 2007, já se manifestam nesse sentido:

Embora se entenda que o tema demandaria uma solução ainda mais abrangente, que implicaria existir apenas dois tipos de prescrição (prescrição da pretensão punitiva calculada pela pena em abstrato e prescrição da pretensão executória calculada pela pena fixada no caso concreto, cujo prazo somente começaria a fluir a partir do trânsito em julgado para ambas as partes), não se pode deixar de reconhecer que a proposta intermediária contida na PL 1.383/2003 configura uma medida de relevo na redução da impunidade.

Não por outra razão, a prescrição retroativa não existe virtualmente em nenhum outro país do mundo. Além da extinção da prescrição retroativa, os prazos prescricionais da pretensão punitiva e da pretensão executória são unificados para passarem a ser guiados pela pena cominada, e não pela pena aplicada, o que em nada prejudica cumprimento individualizado da pena pelo réu e confere uma uniformidade razoável aos prazos prescricionais. De fato, se fazia sentido um prazo prescricional superior até a pena definitiva, o mesmo prazo continua sendo um prazo razoável para ser aguardado antes de se extinguir a pena na hipótese de o réu fugir para evitar a punição.

Poder-se-ia, ainda, pensar na eliminação da própria prescrição da pretensão punitiva pela pena in concreto, denominada "superveniente", incidente entre a sentença de primeiro grau e o trânsito em julgado definitivo da tutela jurisdicional. Há modelos, como o do Código alemão, em que não corre a prescrição após a sentença de $1^{\circ}$ grau e até o trânsito em julgado do feito. Porém, por ora, não se faz esta opção; ao contrário, mantém-se a prescrição superveniente. 
Altera-se a tábua de prazos da pretensão executória. Em geral, nos diversos Códigos Penais do mundo, os prazos para a prescrição da pretensão punitiva - ou da ação - são menores que os prazos da prescrição da pretensão executória - ou da execução. É que, no primeiro interregno, a pretensão de punir não ganhou, ainda, o reforço da tutela jurisdicional que, ao contrário, a confirma e fortalece, após a emissão de sentença condenatória com trânsito em julgado. Assim, os sistemas mantêm lapsos menores para a prescrição, enquanto o interesse de punir não foi confirmado pelo Estado-Juiz; e prazos maiores, quando esse interesse já restou chancelado, ganhando reforço. Do contrário, tem-se diminuição de prazos justamente quando o interesse estatal na punição ganhou estofo. Por essa razão, justifica-se a redação, acima sugerida, de acréscimo em 1/3 nos prazos do art. 109 para estabelecer os períodos de prescrição da pretensão punitiva. Segue-se, aqui, o modelo legislativo do Código Penal uruguaio, art. 129.

A mudança no início da prescrição da pretensão executória, mediante alteração do art. 112 do $\mathrm{CP}$, visa adequar a legislação do Código Penal à recente decisão do STF no HC no 84.078, que entendeu pela impossibilidade de execução provisória da sentença penal condenatória. Em outras palavras, a pena só pode ser executada após o trânsito em julgado da decisão condenatória. Por outro lado, não há sentido em fazer correr o prazo da prescrição da pretensão executória enquanto não é possível dar início à execução!

O problema todo é que a atual interpretação do art. 112, I, dominante nos tribunais - no sentido que a prescrição da pretensão executória começa a correr com o trânsito em julgado para a acusação, ainda que ocorra em primeiro grau e haja sucessivos recursos da defesa - , aliada à possibilidade do início de execução da pena apenas após o trânsito em julgado, faz com que corra o prazo da prescrição executória mesmo sem que seja possível executar a pena do réu. Isso tende a inviabilizar as execuções penais de crimes do colarinho-branco no Brasil e gera a prescrição. A única saída para a acusação, nesse quadro, é recorrer mesmo quando concorda com o teor da decisão, para evitar que o trânsito em julgado para a acusação aconteça antes do trânsito em julgado para a defesa. Isso implica, por sua vez, obrigar o Judiciário a apreciar recursos desnecessários sobre situações em geral complexas, de modo antieconômico e contrário à celeridade do Judiciário.

De resto, não há razoabilidade em começar a contar a prescrição da pretensão executória se não há possibilidade de execução de pena. Como coloca Fabio Guaragni (2008, p. 137): “O que importa, aqui, é a exequibilidade da sentença, inexistente até que esteja firmada para ambas as partes. Importa a 
possibilidade de exercer o jus executionis, vedada enquanto não opera o trânsito em julgado".

O acréscimo de uma causa impeditiva da prescrição ao art. 116, por sua vez, tem por objetivo evitar que os recursos especial e extraordinário, que são interpostos perante as cortes mais atarefadas do país, acabem ensejando a prescrição pelo decurso do tempo, sem que haja inércia da parte. Além disso, a proposta alinha a redação do Código Penal com o que está previsto no Projeto de Lei no 8.045/2010, que reforma o Código de Processo Penal. De fato, o §3o do art. 505 do CPP em trâmite determina a suspensão do prazo prescricional desde a interposição de tais recursos até o trânsito em julgado.

O acréscimo da causa impeditiva ao parágrafo único do art. 116 objetiva obstar que a prescrição flua enquanto o condenado está foragido ou evadido, evitando que ele se beneficie da própria torpeza. Preferiu-se utilizar os termos "foragido" e "evadido" de modo alternativo para evitar possíveis discussões a respeito da abrangência da aplicação do dispositivo às situações de fuga mediante transpasse de obstáculos à liberdade (por exemplo, cavando um túnel na cela) e de simples ausência de retorno quando de saída temporária ou nos regimes aberto e semiaberto.

A alteração do inciso I do art. 117 busca alinhar-se com as demais legislações, demarcando a manifestação do interesse estatal na punição com a oferta da denúncia (e não com seu recebimento pelo Poder Judiciário). Quem embandeira a pretensão punitiva é o titular da ação penal, o Ministério Público (art. 129, I, da CR), bem como - nos casos de lei - o ofendido. Se a prescrição, por definição, é o desinteresse estatal na punição pelo decurso do tempo, o avesso disso - o interesse - arreda a prescrição. Gera o que a dogmática assinala como incompatibilidade entre uma ação penal em movimento e a prescrição. Nesta incompatibilidade radica a ratio das causas interruptivas.

Já o inciso IV do artigo 117, imbuída do mesmo espírito que animou a recente alteração desse inciso, ensejará a interrupção da prescrição quando de qualquer decisão expedida durante a vigência do processo, alinhando-se quase integralmente, aliás, com o texto do Projeto de Lei ㄲo 236/2012, que propõe um novo Código Penal.

Veja-se que, mesmo com a atual redação do dispositivo legal prevendo expressamente que a prescrição se interrompe pelo acórdão condenatório, grande parte dos tribunais confere uma interpretação contra legem ao referido dispositivo, exigindo que o acórdão condenatório seja de reforma da decisão de primeiro grau. 
A adição do inciso VII ao art. 117 tem por propósito harmonizar o tratamento da prescrição com a necessidade de inércia da parte para sua incidência. $\mathrm{O}$ instituto da prescrição objetiva conferir segurança jurídica ao réu quando o autor não adota as providências que lhe são cabíveis (dormientibus non sucurrit jus). Sancionar o autor com a extinção de seu direito quando age de modo diligente, como ocorre hoje, é um contrassenso.

Por fim, o acréscimo do §2ำ ao artigo 337-B do Código Penal vem a atender o disposto no artigo 6 da Convenção sobre o Combate da Corrupção de Funcionários Públicos Estrangeiros em Transações Comerciais Internacionais, promulgada pelo Decreto n⿳0 3.678/2000, que reza: “Artigo 6 - Regime de Prescrição - Qualquer regime de prescrição aplicável ao delito de corrupção de um funcionário público estrangeiro deverá permitir um período de tempo adequado para a investigação e abertura de processo sobre o delito."

\section{Medida 7}

\section{Ajustes nas nulidades penais contra a impunidade e a corrupção}

\section{Ajustes nas nulidades}

\section{Anteprojeto de Lei}

Altera os arts. 157, 563, 564, 567 e 570 a 573 do Decreto-Lei no 3.689, de 3 de outubro de 1941 - Código de Processo Penal, para redefinir o conceito de provas ilícitas e revisar as hipóteses de nulidade.

\section{Justificativa}

1) Conceituação do que seja prova ilícita.

A garantia constitucional da inadmissibilidade das provas ilícitas foi importada do direito norte-americano, onde nasceu a partir de construção jurisprudencial da Suprema Corte dos Estados Unidos da América (SCOTUS). Consiste em um conjunto de regras não escritas na lei, mas reconhecidas pela jurisprudência (no sistema da Common Law boa parte das regras jurídicas é construída pela jurisprudência, através dos chamados precedentes). 
Assim, a SCOTUS decidiu que as provas obtidas em violação à Quarta Emenda à Constituição dos EUA (que assegura a inviolabilidade do cidadão contra buscas e apreensões sem autorização baseada em causa provável), à Quinta Emenda (que assegura o devido processo legal e o direito à não autoincriminação) e à Sexta Emenda (que assegura ao acusado um julgamento público, imparcial, com direito de defesa e a conhecer a acusação que pesa contra si e quem o está acusando) são inadmissíveis no processo criminal (exclusionary rules).

Releva observar que, no direito norte-americano (onde a regra nasceu e de onde veio importada para o direito brasileiro), as "exclusionary rules" aplicam-se tão somente aos processos criminais e se destinam a prevenir que os agentes do estado violem direitos constitucionais para obter provas e delas se utilizem contra o suspeito da prática de crime. Em outras palavras, as regras de inadmissibilidade das provas ilícitas, no direito norte-americano, objetivam dissuadir os policiais de violar direitos constitucionais e, ao mesmo tempo, fornecem remédios aos réus ou investigados que tiveram seus direitos violados.

Nos Estados Unidos, as exclusionary rules não são, elas próprias, um direito constitucional, isto é, não estão previstas nem na Constituição americana, nem em qualquer uma de suas emendas. São elas, como já dito, criações jurisprudenciais, baseadas em precedentes, que se destinam a proteger os direitos constitucionais de investigados e réus.

A sua importação para o Brasil, onde vigora o sistema da Civil Law, deuse mediante positivação da regra no texto constitucional, de modo que a inadmissibilidade das provas ilícitas é, por si só, uma garantia constitucional que, ademais, diferentemente dos Estados Unidos, se aplica tanto ao processo criminal quanto ao processo não criminal. A inadmissibilidade das provas ilícitas, por aqui, é irrestrita.

Quando da importação para o Brasil, mais precisamente em relação à conceituação do que seja prova ilícita e quais seriam as hipóteses excludentes de ilicitude, o legislador brasileiro, inexplicavelmente, se divorciou da origem e se distanciou dos objetivos que levaram à criação das "exclusionary rules" e criou um sistema de regras próprio, que, além de disfuncional, possui caráter extremamente subjetivo, que traduz em insegurança jurídica, conduz a decisões seletivas, transforma o processo em uma autêntica loteria e resulta em impunidade.

Daí as mudanças ora sugeridas. 
A primeira delas na própria conceituação do que seja prova ilícita. A lei em vigor conceitua provas ilícitas como sendo "as obtidas em violação a normas constitucionais ou legais". O conceito é por demais amplo e permite a anulação de provas (o sepultamento de grandes operações policiais de combate ao crime ou de complexas ações penais em fases avançadas ou até mesmo já julgadas) por inobservância de uma simples formalidade, por menor importância que tenha, mesmo que isso não implique violação de direito ou garantia do investigado.

Mas não é só. A amplitude do conceito em vigor leva a interpretações subjetivas, que por sua vez conduzem a decisões seletivas, conforme denunciado na tese de mestrado de Diogo Castor de Mattos, intitulada A seletividade penal na utilização abusiva do "habeas corpus" dos crimes do colarinho-branco.

O referido pesquisador, após analisar decisões do STJ e comparando julgamentos de crimes do colarinho-branco com julgamentos de outros crimes, cujos réus não eram políticos nem empresários abastados, mas assistidos da Defensoria Pública, acusados de latrocínio, tráfico de drogas e lesão corporal, constatou que os argumentos usados pelos Ministros do STJ para anularem as ações penais em casos de crimes graves praticados por ricos ou poderosos não acudiram acusados menos endinheirados.

Contudo, como se viu, as exclusionary rules foram criadas para proteger os direitos constitucionais do investigado ou do réu e não para tutelar formalidades, muito menos para adicionar variáveis aleatórias, próprias das loterias e dos jogos de azar, ao processo criminal. Assim, sugere-se que sejam consideradas ilícitas as provas obtidas com violação aos direitos ou garantias legais ou constitucionais.

Mas não é só. Considerada a finalidade dissuasória das exclusionary rules, a praticidade e a objetividade própria da jurisprudência americana identificaram e reconheceram várias exceções à regra da inadmissibilidade, que se constituem verdadeiras "excludentes de ilicitude da prova". De fato, sempre que a regra de exclusão não tiver o condão de dissuadir os agentes do estado ou moldar a sua conduta com vistas ao respeito aos direitos e garantias do investigado ou réu, ela não deve ser utilizada.

A importação para o Brasil das regras de exclusão das provas ilícitas veio acompanhada de duas causas excludentes de ilicitude reconhecidas pela jurisprudência da SCOTUS, ou seja, circunstâncias que, acaso presentes, permitem a utilização da prova. São elas:

a) a não evidência de nexo de causalidade com as provas ilícitas (independent source doctrine) $\mathrm{e}$ 
b) quando as provas derivadas puderem ser obtidas de uma fonte independente das primeiras, assim entendida aquela que por si só, seguindo os trâmites típicos e de praxe, próprios da investigação ou instrução criminal, seria capaz de conduzir ao fato objeto da prova (inevitable discovery).

Contudo, há diversas outras causas excludentes de ilicitude da prova, já admitidas pela SCOTUS, que ainda não foram positivadas no direito brasileiro, e que o projeto pretende corrigir. São elas:

1) A exceção de boa-fé (good faith exception): em Arizona vs. Evans, 514 U.S.1 (1995), Davis vs. U.S. 131 S.Ct. 2419 (2011) e Herring vs. U.S., 555 U.S. 135 (2009), a SCOTUS decidiu que não se deve excluir a prova quando o policial a tiver obtido de boa-fé ou por erro escusável, assim entendida a existência ou inexistência de circunstância ou fato que o levou a crer que a diligência estava legalmente amparada, como, por exemplo, quando o mandado contiver dados incorretos ou vier a ser posteriormente anulado.

Entendeu-se que, nessas circunstâncias, a exclusão da prova não produziria o efeito dissuasório desejado, de evitar que os policiais, no futuro, voltassem a violar direitos constitucionais dos investigados.

2) Causa remota, atenuada ou descontaminada (attenuation doctrine), quando houver decorrido muito tempo entre a violação da garantia e a obtenção da prova, tornando remota a relação de dependência ou consequência, ou quando fato posterior a houver descontaminado ou atenuado essa relação, como, por exemplo, quando o investigado resolver se tornar colaborador.

3) Contraprova (evidence admissible for impeachment): Quando a prova for utilizada pela acusação para refutar álibi, fazer contraprova de fato inverídico deduzido pela defesa ou demonstrar a falsidade ou inidoneidade de prova por ela produzida, não podendo, contudo, servir para demonstrar culpa ou agravar a pena.

Além das excludentes de ilicitude consagradas pelo direito norte-americano, outras causas devem igualmente ser incluídas, tendo em vista a relevância de seus objetivos ou o fato de estarem sob o pálio de circunstância protegida pela lei penal. São elas:

I - Destinadas a provar a inocência do réu ou reduzir-lhe a pena (o sacrifício de direito ou garantia individual é justificado pelo objetivo maior, que é o de evitar que um inocente seja condenado ou fique mais tempo preso do que o devido).

II - Obtidas por quem, no exercício de suas atividades regulares, toma conhecimento do crime e o leva ao conhecimento das autoridades (whistleblower). 
III - Obtidas por quem se encontre amparado por uma das causas que a lei penal classifique como excludente de ilicitude, tais como, a legítima defesa, o exercício regular do direito e o estrito cumprimento do dever legal.

2) Ampliação das preclusões de alegações de nulidades.

Não se pode tolerar que as partes dolosamente deixem de alegar nulidades, guardando trunfos na manga para, anos, às vezes décadas, depois, alegar os vícios em grau recursal e obter anulações, não raro visando à prescrição dos delitos imputados. Se há nulidade, a parte deve alegá-la na primeira oportunidade que tem para se manifestar, e o juiz deve decidi-la dentro de marcos próprios da evolução do processo.

3) Nas omissões em alegar nulidades, a superação de preclusões deve ser condicionada à interrupção da prescrição a partir do momento em que a parte deveria ter alegado o defeito.

A omissão em alegar deve gerar preclusão. Apesar da sua omissão, e a fim de valorizar a ampla defesa, a parte poderá postular do juízo a superação da preclusão, com a consequente anulação e repetição do ato. Todavia, o retrocesso a fases anteriores do procedimento, por ter sido culposamente causado pela parte, não pode levar à prescrição se a parte sabia ou deveria saber do defeito. Assim, impende haver interrupção da prescrição a contar da data em que a parte deveria ter alegado o defeito.

4) O aproveitamento máximo dos atos processuais praticados deve ser um dever do juiz e das partes. A pronúncia de nulidade deve exigir fundamentação específica e concreta.

A doutrina praticamente unânime já afirma que a invalidação deve ser medida excepcional, e que todos os atos processuais devem ser, de regra, aproveitados. Haverá casos, contudo, em que um defeito formal pode gerar um prejuízo irreparável, não sanável, ao exercício do direito de defesa (como afirma a lei) e, acrescentamos, também ao contraditório, quando então pode ser justificada a invalidação. Essa alegação e demonstração deve ser feita em concreto pelo requerente, exigindo-se, também, do juízo fundamentação específica para que se invalide o ato considerado viciado.

5) Impossibilidade de presunção de prejuízo, exigindo-se que as partes demonstrem especificamente, à luz de circunstâncias concretas, o impacto 
que o defeito dos atos processuais tenha gerado ao exercício dos seus direitos constitucionais.

É muito comum ver nas fundamentações de invalidação afirmações de que, naquele caso, o "prejuízo se presume". A lógica do processo contemporâneo é de aproveitamento dos atos e que as nulidades sejam sempre excepcionais. Portanto, a invalidação não pode ser tendencial ou presumida. Para invalidar um ato deve-se exigir alegação e demonstração concreta.

Observe-se, aí, que o antigo rol de atos que ensejariam nulidade, do art. 564, foi suprimido. O formato do Código de Processo Penal, de fato, previa uma lista de vícios de atos processuais que poderiam levar à sua invalidação. Ora, essa opção metodológica, além de medieval, porque guarda raízes no processo romano formular, é desastrosa, porque o legislador não pode prever todos os defeitos que a riqueza das circunstâncias fáticas pode apresentar em juízo. Melhor adotar a opção do Código de Processo Civil e da maior parte das legislações no mundo, de adotar uma cláusula geral sobre as formas e aproveitamento dos atos processuais.

A proposta do art. 573 está em consonância com a moderna orientação de uma das principais fontes, se não a principal, de nossa teoria moderna de nulidades.

Além disso, a alteração ora proposta coloca em perspectiva a decretação da nulidade, frisando que ela não pode ser um fim que serve a si próprio, mas um meio para atingir uma finalidade maior. Mais ainda, essa finalidade atingida pela nulidade deve ser mais importante do que a finalidade atingida pelo aproveitamento da prova.

\section{Medida 8}

Responsabilização dos partidos políticos e criminalização do "Caixa 2"

\section{Responsabilização dos partidos políticos e criminalização do "Caixa 2"}

\section{Anteprojeto de Lei}

Altera a Lei oㅜ 9.096, de 19 de setembro de 1995, a fim de prever a responsabilização dos partidos políticos por atos 
$[\ldots]$

de corrupção e similares; acrescenta os arts. 32-A e 32-B à Lei no 9.504, de 30 de setembro 1997, para tornar crime o caixa 2, e altera a redação do art. 105-A da mesma lei.

\section{Justificativa}

A contínua evolução da legislação brasileira relativa ao combate à corrupção administrativa, como dá exemplo a Lei oㅡ 12.846, de 1o de agosto de 2013, demonstra a necessidade de trazer, também para o ambiente eleitoral, inovações. É um ambiente no qual, diante da relação de proximidade em si mesma, neutra - entre partidos políticos e a administração pública e dos altos custos das campanhas eleitorais, situações de ilicitude podem ser propiciadas. O objetivo da proposição é estender às agremiações partidárias exigências feitas hodiernamente para quaisquer pessoas jurídicas. Secundariamente, pretende evitar que, por lacuna legal, ilícitos praticados noutras áreas e com finalidades diversas sejam, como estratégia de exclusão ou minoração das sanções, atribuídas às disputas eletivas. Assim, se a referida lei trouxe a responsabilidade objetiva das pessoas jurídicas por atos contra a administração pública, é conveniente que também os partidos políticos, que manejam recursos públicos e privados, se insiram no campo da responsabilização. Dessa forma, os arts. 49-A, 49-B e 49-C, propostos para a Lei Orgânica dos Partidos Políticos, Lei no 9.096/1995, trazem o cerne da Lei 12.846/2013. Normas relativas a procedimentos, bem como a sanções, tiveram previsão autônoma, considerada a natureza peculiar dos partidos políticos. É por esta razão que não se propõe a pura e simples aplicação daquela lei aos partidos e se afastam medidas como os acordos de leniência ou regras sobre processo que não dizem respeito às realidades da Justiça Eleitoral e do Ministério Público Eleitoral.

$\mathrm{O}$ art. 49-A proposto prevê a responsabilidade dos partidos políticos pelos atos ilícitos descritos no art. 5으 da Lei 12.846/2013 e, também, por condutas de "Caixa 2", "lavagem de capitais" e utilização de doações de fontes vedadas. Ele traz um roteiro para a aplicação das sanções, limitadas, a princípio, à esfera partidária responsável pela prática dos atos irregulares. O art. 49-B descreve a extensão e o modo de cálculo das sanções propostas, e o art. 49-C, a legitimação e o rito processual das ações a serem levadas à Justiça Eleitoral.

Propõe-se, também, a alteração da Lei das Eleições, Lei no 9.504/1997, para tipificar, como crime, a conduta do "Caixa 2" - art. 32-A - e a variante eleitoral da Lavagem de Dinheiro, art. 32-B. São situações que apresentam 
"dignidade penal", em razão de sua grande repercussão nas disputas eleitorais, que podem ser por essa prática desequilibradas. Além disso, há insuficiência das sanções extrapenais, como a rejeição das contas de candidatos ou partidos e mesmo a cassação do diploma que, por definição, só alcança candidatos eleitos. A quantidade de pena prevista para a conduta eleitoral de "lavagem" corresponde às penas da Lei no 12.683, de 9 de julho de 2012, especialmente para evitar que ilícitos de idêntica gravosidade recebam sanção distinta.

Por fim, faz-se a proposição de inclusão de um parágrafo único no artigo 105-A da lei referida, para regulamentar o procedimento preparatório de alçada do Ministério Público Eleitoral, hoje previsto apenas em normativa infralegal.

\section{Medida 9}

\section{Prisão preventiva para evitar a dissipação do dinheiro desviado}

\section{Prisão preventiva}

\section{Anteprojeto de Lei}

Altera a redação do art. 312 do Decreto-Lei no 3.689 , de 3 de outubro de 1941 - Código de Processo Penal, a fim de prever a possibilidade de prisão preventiva para evitar dissipação do dinheiro desviado.

\section{[...] Justificativa}

A proposta visa incluir a possibilidade de decretação da prisão preventiva para permitir a identificação e a localização do produto do crime ou seu equivalente e assegurar sua devolução. Prestigiam-se e até mesmo ampliamse, assim, os ideais da Justiça Restaurativa, que tem como um dos objetivos a reparação dos danos causados pelo crime.

A medida busca, ainda, dificultar ao investigado ou acusado a ocultação do produto do crime. Também impede que o produto do crime seja utilizado para buscar a impunidade do infrator, seja dando-lhe meios de fuga, seja custeando sua defesa criminal. Como bônus, a medida permite ainda estrangular a capacidade financeira de origem ilícita do criminoso (ou seu equivalente) e impedir que usufrua os lucros do crime. 
A medida preventiva não será cabível, evidentemente, se restar evidenciado que o acusado já dissipou integralmente os ativos ilícitos e seu equivalente.

Não se trata de impor algum tipo de prisão por dívida, ainda que por meios transversos. A ocultação de dinheiro desviado é, em geral, um ato de lavagem de dinheiro praticado de modo permanente. A prisão acautela a sociedade contra a continuidade e reiteração na prática de crimes que, segundo as circunstâncias evidenciam, estão se repetindo e protraindo no tempo. Trata-se de uma proteção da ordem pública contra novos ilícitos.

Ressalte-se que a prisão preventiva, na hipótese ora aventada, continua a ser medida excepcional, como deve ser, cabível apenas quando as medidas cautelares reais forem ineficazes ou insuficientes ou enquanto estiverem sendo implementadas. Com isso, evita-se a sua banalização e preserva-se seu caráter de recurso excepcional, um remédio amargo, aqui, para evitar a sangria dos recursos ilícitos em proveito do criminoso e prejuízo da sociedade.

\section{Multa aos bancos por descumprimento de ordem judicial}

\section{Anteprojeto de Lei}

Altera o art. 17-C da Lei no ${ }^{9} .613$, de 3 de março de 1998, para estabelecer o pagamento de multa em caso de descumprimento de ordem judicial por instituições financeiras obrigadas a prestar informações bancárias e fiscais.

\section{$[\ldots]$ \\ Justificativa}

As alterações feitas no caput são nada mais do que hermenêutica autêntica da lei, a qual objetiva explicitar a interpretação que já vem recebendo. As disposições previstas nos parágrafos são essenciais para conferir maior efetividade às quebras de sigilo bancário e rastreamento de recursos, em razão de diversos problemas no atendimento de ordens judiciais por instituições financeiras.

Muito embora já se tenha avançado significativamente com o desenvolvimento de um canal eletrônico de comunicação com Instituições Financeiras, para recebimento de dados bancários padronizados, o Sistema de Investigação 
de Movimentações Bancárias (SIMBA), já instalado em diversas instituições, verifica-se que vários bancos, na maior parte dos casos, são recalcitrantes na prestação de informações completas.

O caso Lava Jato é expressão desse problema. Empresas utilizadas para fins criminosos, como a Empreiteira Rigidez, a MO Consultoria, a GFD Investimentos, a RCI e outras pessoas físicas e jurídicas, tiveram seu sigilo bancário afastado nos autos do Processo 5027775- 48.2013.404.7000. A decisão foi encaminhada ao Banco Central, e posteriormente encaminhada aos bancos, em 30 de junho de 2014, com prazo de 30 dias para cumprimento da ordem judicial.

A título de exemplo, em 20 de agosto de 2014, daquelas quebras determinadas em 30 de junho, ainda estavam pendentes 135 contas, sendo 19 da CEF, 93 do Bradesco, 6 do HSBC, 5 do Banco Sofisa, 4 do Pine e 8 do Santander. Após novo requerimento do Ministério Público Federal, a Justiça Federal reiterou a ordem aos bancos em 10 de setembro de 2014. Somente no final de outubro foram recebidas pelo MPF as informações das últimas contas pendentes, aproximadamente quatro meses após as quebras, em caso de repercussão envolvendo réus presos e crimes extremamente graves. Mesmo assim, em muitas das operações bancárias informadas, os bancos não identificaram o beneficiário ou a origem dos recursos. A falta de identificação de origem e destino impede o rastreamento dos recursos, isto é, mesmo 4 meses depois da ordem judicial, informações bancárias indispensáveis não foram prestadas pelas instituições financeiras.

Não é possível esperar quatro meses para poder rastrear recursos quando criminosos os movem com a rapidez de um "clique" de computador. O problema atual e sério que se busca solucionar é o fato de que, sem um rastreamento célere, não é possível alcançar e apreender recursos desviados, nem investigar adequadamente crimes graves. A medida proposta objetiva criar um mecanismo de efetivo incentivo para que as instituições financeiras cumpram seu papel de contribuir com o funcionamento de mecanismos de combate à lavagem de dinheiro.

Em outra quebra de sigilo bancário da Operação Lava Jato, os bancos foram comunicados da ordem judicial em 28 de agosto de 2014, com prazo de 30 dias, para cumprimento da decisão judicial, mas até 15 de novembro de 2014 não tinham cumprido integralmente a ordem.

Além disso tudo, muitas vezes é difícil conseguir contato, ainda mais pessoal, com as pessoas dos bancos que são responsáveis pelo cumprimento das ordens judiciais, a fim de garantir um resultado efetivo e em prazo adequado. 


\title{
Medida 10
}

\section{Medidas para recuperação do lucro derivado do crime}

\author{
19. Confisco alargado
}

Anteprojeto de Lei

Acrescenta o art. 91-A ao Decreto-Lei no 2.848, de 7 de dezembro de 1940 - Código Penal, para tornar possível o confisco alargado.

$[\ldots]$

Justificativa

O dispositivo introduz o confisco alargado na legislação brasileira, cumprindo diretrizes de tratados dos quais o Brasil é signatário e adequando o sistema jurídico pátrio a recomendações de fóruns internacionais voltados a coibir o crime organizado.

O dispositivo proposto também harmoniza a legislação brasileira com sistemas jurídicos de outros países que já preveem medidas similares e com os quais o Brasil mantém relações e acordos de cooperação, permitindo a reciprocidade e o combate a crimes graves de efeitos transnacionais.

O confisco alargado visa a instituir de maneira mais efetiva a ideia clássica de que "o crime não compensa", ou, mais precisamente, não deve compensar. Em crimes graves que geram benefícios econômicos ilícitos, incumbe ao Estado, tanto quanto a punição dos responsáveis, evitar o proveito econômico da infração e a utilização do patrimônio decorrente da atividade criminosa em outros delitos. Mas a persecução criminal do Estado não é, não pode e até mesmo não deve ser exaustiva. Nem todas as infrações podem ser investigadas e punidas, inclusive por força das garantias constitucionais e legais dos cidadãos.

O confisco clássico e o confisco por equivalente, previstos hoje na legislação penal brasileira (art. 91 do Código Penal), alcançam, além dos instrumentos do crime que sejam em si ilícitos (art. 91, "a", do Código Penal), apenas os bens ou valores correspondentes que sejam produto ou proveito da específica infração objeto da condenação criminal. Mas, conforme já se anotou, há situações em que não é possível identificar ou comprovar, nos termos 
exigidos para uma condenação criminal, a prática de crimes graves que geram benefícios econômicos, embora as circunstâncias demonstrem a origem ilícita do patrimônio controlado por determinadas pessoas. Nesses casos, sem a possibilidade de se promover a responsabilidade criminal, o confisco clássico e o confisco por equivalente não são capazes de evitar o proveito ilícito e a utilização desse patrimônio de origem injustificada em novas atividades criminosas. O instituto ora proposto visa, assim, a criar meio de retirar o patrimônio de origem injustificada do poder de organizações e de pessoas com atividade criminosa extensa que não possa ser completamente apurada.

O confisco alargado ora proposto, na esteira da legislação de outros países, tem como pressuposto uma prévia condenação por crimes graves, listados no dispositivo, que geram presunção razoável do recebimento anterior de benefícios econômicos por meios ilícitos. Estabelece, nesses casos, um ônus probatório para a acusação acerca da diferença entre o patrimônio que esteja em nome do condenado, ou que seja por ele controlado de fato, e os seus rendimentos lícitos, ressalvando também a possibilidade de JUSTIFICATIVA por outras fontes legítimas que não decorram diretamente desses rendimentos. É garantida ao condenado oportunidade de demonstrar a legalidade do seu patrimônio, bem como aos terceiros indevidamente afetados pela decretação da perda ou pela constrição cautelar de bens.

Como se trata de medida que atinge apenas o patrimônio de origem injustificada, sem imputar ao afetado nenhum dos efeitos inerentes a uma condenação criminal pelos fatos que ensejaram a posse desses bens, o confisco alargado se harmoniza com o princípio da presunção de inocência, conforme tem sido reconhecido em outros países e em organismos e fóruns internacionais.

Compatibilizando o instituto proposto com a legislação processual penal atual, e na esteira do que estabelece o Código Penal a respeito do confisco por equivalente recentemente instituído ( $\$ 2^{\circ}$ do art. 91, incluído pela Lei no $12.684 / 2012$ ), a proposta ressalta a aplicação das medidas cautelares reais penais para a garantia do confisco alargado. Também prevê expressamente a possibilidade de alienação antecipada de coisas sujeitas a deterioração ou depreciação, evitando que o tempo necessário para a decisão acerca do confisco resulte em perdas econômicas ou em prejuízos para o acusado ou terceiro de boa-fé.

Considerando tratar-se de um dos efeitos da condenação criminal, o projeto prevê que o cumprimento da sentença que decretar o confisco alargado, após o trânsito em julgado, será processado, no prazo de até dois anos, no 
juízo criminal que proferiu a decisão. Nessa fase, o Ministério Público, com base no título jurídico judicial, deverá alegar e comprovar o patrimônio do condenado que não é compatível com os seus rendimentos lícitos e que também não tem outra origem lícita conhecida, segundo as informações públicas disponíveis. Remete-se o procedimento à legislação processual civil - permitindo a aplicação das normas de liquidação por artigos e de cumprimento de sentença do Código de Processo Civil.

A proposta, portanto, visa a atualizar e compatibilizar a legislação brasileira com o que vige no cenário internacional, conferindo ao Estado um instrumento de combate aos ganhos ilícitos decorrentes do crime em harmonia com os primados do Estado Democrático de Direito, fazendo valer a máxima de que o crime não deve compensar.

\section{Ação de extinção de domínio}

\section{Anteprojeto de Lei}

Disciplina a ação para extinção de domínio sobre bens de qualquer natureza, ou valores, que sejam produto ou proveito, direto ou indireto, de atividade ilícita ou com as quais estejam relacionados na forma desta lei, e na sua transferência em favor da União, dos Estados ou do Distrito Federal, sem direito a indenização.

\section{Justificativa}

O anteprojeto de lei para disciplinar a perda civil de bens adquiridos com a prática de ilícito (ação de extinção de domínio) foi exaustivamente estudado e discutido durante metas e ações da Estratégia Nacional de Combate à Corrupção e Lavagem de Ativos (ENCCLA) em 2005, 2010 e 2011. O fruto do debate foi a unanimidade dos diversos órgãos que compõem aquele foro em torno do projeto acima, o qual é o resultado final da ação 16 da ENCCLA, referente ao ano de 2011.

A única diferença entre o projeto da ENCCLA e o ora apresentado consiste em correção de erro material na menção, pelo artigo 2o do anteprojeto, ao artigo do Código Penal que corresponde ao crime de inserção de dados falsos em sistemas de informações, bem como na inserção do crime de enriquecimento ilícito, cuja tipificação é proposta em projeto de lei oferecido em apartado. 
São reproduzidas abaixo as justificativas apresentadas como produto das discussões desenvolvidas durante os trabalhos da ação 16 da ENCCLA:

A extinção civil do domínio, ou perda civil de bens, no direito estrangeiro, é conceituada como a privação do direito de propriedade sem qualquer compensação a seu titular, em razão de aquela ter sido usada de maneira contrária às determinações legais do ente soberano. Num contexto mundial de busca ao intensivo combate à prática de lavagem de dinheiro, os organismos internacionais recomendam a implementação, por parte das nações, de legislação que autorize a extinção civil de domínio in rem ou perda civil de bens.

No Brasil, o fundamento constitucional que autoriza a expropriação sem indenização da propriedade ou posse, em razão do descumprimento de sua função social, encontra lastro no artigo 5o, inciso XXIII, da Constituição Federal de 1988, que reza: “a propriedade atenderá a sua função social".

A natureza jurídica do instituto conforma-se com uma compensação, uma reparação devida pelo proprietário ao Estado, em razão de ter aquele usado ou permitido que se usasse o bem objeto de perdimento contrariamente ao que estabelece o ordenamento jurídico que, em última instância, autoriza, legitima e protege o próprio exercício do direito à propriedade.

A perda civil da propriedade apresenta dupla finalidade: diminuir a capacidade de ação das organizações criminosas pela retirada de seus meios materiais de atuação e ampliar a capacidade material de combate aos males gerados por essa mesma atuação por via de transferência dos produtos da ação civil de perdimento in rem à pessoa jurídica de direito público afetada pelas práticas ilícitas.

Uma vez explicitada a natureza jurídica do instituto, passa o texto do anteprojeto de lei a tratar das hipóteses em que a perda civil pode ser declarada, as quais correspondem às teorias reconhecidas pela doutrina internacional a embasar o perdimento. $\mathrm{O}$ substrato dos casos que autorizam a perda civil consiste na vinculação, de qualquer forma, do bem, direito ou valor com atividades ilícitas.

Entretanto, tais atividades se restringem àquelas enumeradas no $\S 1^{\circ}$ do artigo $2 \stackrel{\circ}{ }$, por serem consideradas de alta gravidade e reprovabilidade no meio social, estando intrinsecamente relacionadas às práticas de organizações criminosas. 
Quando as atividades ilícitas tenham sido praticadas no estrangeiro, caberá a perda civil dos bens, direitos ou valores situados no Brasil, nos termos do artigo 3으.

Ainda com escopo de reduzir a margem de ação de tais organizações criminosas, no $\S 2^{\circ} \stackrel{\circ}{ }$ do artigo $2^{\circ}$, abre-se a possibilidade de perda civil de bens transmitidos a terceiros por meio de herança, legado ou doação, tudo de forma a não permitir aos perpetradores do ilícito escamotear seus proveitos via transmissão de seu direito.

De outro lado, preocupa-se o texto do anteprojeto de lei em garantir os direitos do lesado e do terceiro de boa-fé, em consonância com as disposições do Código Civil que guindou a boa-fé ao status de regra de interpretação (artigo 113) e princípio geral com relação aos contratos (artigo 422).

O artigo $4^{\circ}$ prevê que os legitimados - Ministério Público, União, Estados e Distrito Federal - poderão instaurar procedimento preparatório ao ajuizamento da ação de declaração da perda civil da propriedade ou posse em razão do descumprimento da sua função social.

O contraditório e a ampla defesa estão e permanecem garantidos no anteprojeto de lei, o qual adota para a ação de perda civil de bens o rito da ação civil pública, instituída pela Lei no 7.347, de 24 de julho de 1985, e, subsidiariamente, a Lei no 5.869, de 11 de janeiro de 1973 - Código de Processo Civil.

O trâmite da ação de perda civil de bens independe de eventuais processos civis ou penais que incidem sobre os mesmos fatos, eis que tais processos buscam a responsabilização pessoal por atos ilícitos. Por óbvio, a independência de instâncias não se aplica quando houver sentença penal absolutória que taxativamente reconheça a inexistência do fato ou não ter sido o agente, quando proprietário do bem, o seu autor. A perda civil da propriedade ou posse abrange também situações em que a persecução penal ou civil não se faz possível, por ausência ou desconhecimento do responsável, ou ainda por falta de definição precisa da responsabilidade civil ou penal, o que não impede, contudo, que provas suficientes existam da origem ilícita dos bens e direitos.

Os artigos 8ํ e 9o fixam como legitimados passivos para a ação de perda civil de propriedade ou posse os titulares ou possuidores dos bens adquiridos, originários ou envolvidos com atividades ilícitas. Trata-se, portanto, de ação propter rem. 
Está estabelecido ainda que a ação poderá ser intentada contra réu incerto, se desconhecido proprietário ou possuidor, caso em que serão citados por edital os interessados, com descrição dos bens, e nomeado pelo juiz curador para defender e proteger os interesses dos réus não conhecidos.

A qualquer tempo em que surja o titular ou possuidor, poderá ingressar no feito, recebendo-o na fase e estado em que se encontra, de forma também coerente com a legislação civilista.

$\mathrm{O}$ artigo 10 define como competente, primariamente, o foro do local do fato ilícito ou dano, porquanto recomendável que o processo tramite no juízo que detenha jurisdição no território em que ocorrido o originário ilícito ou dano, mais próximo que está da prova a ser analisada e dos fatos.

Não sendo conhecido, eventualmente, o local do ilícito, poderão ser eleitos, alternativamente, o foro de situação dos bens ou aquele de domicílio do réu, ambas as alternativas igualmente justificáveis e coerentes com a legislação civil.

O artigo 11 prevê que o poder de cautela do juiz pode ser utilizado, a qualquer tempo, para concessão de quaisquer medidas de urgência que se mostrem necessárias para garantir a eficácia do provimento final.

O $\S 1^{\circ}$ do artigo 11 fixa o prazo de 60 (sessenta) dias - prorrogável por igual período, desde que fundamentadamente justificado ao juiz da causa - para vigência de medidas preparatórias. Este rigor garante os direitos individuais, ao tempo em que exigirá do Estado cautela e disciplina extremadas na iniciativa e no próprio pedido de medidas cautelares quaisquer.

Rezam os $\$ \S^{\circ}$ e $4^{\circ}$ do artigo 11 que, realizada a apreensão do bem, o processo judicial passará a ter prioridade na tramitação, devendo o juiz deliberar, de imediato, sobre sua alienação antecipada ou sobre nomeação de administrador.

Tais linhas de conduta visam garantir a tramitação célere, a eficácia da medida final e a garantia dos réus, pois proporcionam a manutenção do valor real do bem, desde sua constrição.

O anteprojeto de lei prevê que a alienação antecipada será realizada por meio de leilão, não sendo admitido preço vil, ficando o depósito dos valores em contas remuneradas vinculadas ao juízo. 
O artigo 15 dispõe em seu caput a consequência lógica de que, julgado procedente o processo, determinará o juiz as medidas necessárias para transferência definitiva dos bens, direitos e valores discutidos.

Ao mesmo tempo, o parágrafo único dispõe que a sentença pela improcedência por eventual insuficiência de provas não faz coisa julgada material, podendo qualquer dos legitimados propor nova ação com o mesmo objetivo, desde que lastreada em nova prova.

A redação dada ao caput do artigo 16 denota o interesse público subjacente à perda civil da propriedade ou posse, de modo que se optou por dispensar os legitimados do adiantamento de custas, emolumentos, honorários periciais, honorários sucumbenciais e demais despesas, salvo comprovada má-fé do autor.

Os parágrafos do artigo 16 especificaram essa regra, determinando a preferência de se realizar perícias por meio de peritos integrantes do quadro da Administração Pública.

Excepcionalmente, as perícias serão realizadas por profissionais estranhos à Administração Pública, caso em que as despesas periciais serão adiantadas pelos entes públicos, já que serão estes, em caso de procedência do pedido, os beneficiários ao final do processo. Tais despesas serão pagas pelo réu sucumbente.

$\mathrm{O}$ art. 18 introduz salutar regra de recompensa ao terceiro desvinculado de qualquer delito correlato que contribua de modo eficaz, preste informações que levem a obtenção de provas que possam instruir a ação declaratória de perda civil ou a localização de bens. Com isso, fará jus a até cinco por cento do produto da liquidação dos bens objeto da perda civil.

Por fim, o anteprojeto de lei vai ao encontro da postura institucional da República Federativa do Brasil, que sempre se posicionou, na arena internacional, pela repressão aos crimes praticados por organizações criminosas e pela adoção do consenso fruto das negociações multilaterais. 